\title{
Letter Report: Cold Crucible Melter
} Assessment

M.L. Elliott

March 1996

Prepared for the U.S. Department of Energy under Contract DE-AC06-76RLO 1830

Pacific Northwest National Laboratory Operated for the U.S. Department of Energy by Battelle Memorial Institute 
PNNL-11018

UC-810

Project Technical Information

\title{
Letter Report: Cold Crucible Melter Assessment
}

\author{
M. L. Elliott
}

March 1996

Prepared for

the U.S. Department of Energy

under Contract DE-AC06-76RLO 1830

Pacific Northwest National Laboratory

Richland, Washington 99352

Reprint of historical document PVTD-C94.04.20B, dated March 1994. Data, formatting, and other conventions reflect standards at the original date of printing. Technical peer reviews and editorial reviews may not have been performed. 


\title{
DISCLAIMER
}

This report was prepared as an account of work sponsored by an agency of the United States Government. Neither the United States Government nor any agency thereof, nor Battelle Memorial Institute, nor any of their employees, makes any warranty, express or implied, or assumes any legal liability or responsibility for the accuracy, completeness, or, usefulness of any information, apparatus, product, or process disclosed, or represents that its use would not infringe privately owned rights. Reference herein to any specific commercial product, process, or service by trade name, trademark, manufacturer, or otherwise does not necessarily constitute or imply its endorsement, recommendation, or favoring by the United States Government or any agency thereof, or Battelle Memorial Institute. The views and opinions of authors expressed herein do not necessarily state or reflect those of the United States Government or any agency thereof.

\author{
PACIFIC NORTHWEST NATIONAL LABORATORY \\ operated by \\ BATTELLE \\ for the \\ UNITED STATES DEPARTMENT OF ENERGY \\ under Contract DE-AC06-76RLO 1830
}

\author{
Printed in the United States of America \\ Available to DOE and DOE contractors from the \\ Office of Scientific and Technical Information, P.O. Box 62, Oak Ridge, TN 37831; \\ prices, available from (615) 576-8401.
}

Available to the public from the National Technical Information Service, U.S. Department of Commerce, 5285 Port Royal Rd., Springfield, VA 22161 


\section{INTRODUCTION}

One of the activities of the PNL Vitrification Technology Development (PVTD) Project is to assist the Tank Waste Remediation Systems (TWRS) Program in determining which melter systems should be performance tested for potential implementation in the high-level waste (HLW) vitrification plant. The Richland Operations Office (RL) has recommended that the Cold Crucible Melter (CCM) be evaluated as a candidate "next generation" melter'. As a result, the CCM System Evaluation cost account was established under the PVTD Project so that the CCM could be initially assessed on a high-priority basis. This letter report summarizes a brief initial review and assessment of the CCM. Using the recommendations made in this document, Westinghouse Hanford Company (WHCl and RL will make a decision regarding the urgency. of performance testing the CCM. If the decision is favorable, a subcontract will be negotiated for performance testing of a CCM using Hanford HLW simulants in a pilot-scale facility.

Because of the aggressive nature of the schedule, the CCM evaluation was not rigorous. The evaluation consisted of a literature review and interviews with proponents of the technology during a recent trip to France. This letter report summarizes the evaluation and makes recommendations regarding further work in this area.

\section{BACKGROUND}

The CCM (also referred to as the Cold Wall Melter and the Two-Stage Vitrification System) is not a new concept. The technology stems from a 1925 German patent. Battelle Pacific Northwest Laboratories used this technique to melt reactive metals in the 1970s. In 1980 the Commissariat A L'Énergie Atomique (CEA) used direct induction heating to meit metal wastes from nuclear fuel reprocessing. This experience led to the development of a CCM for inductively heating glass in a water cooled crucible. Similar development was conducted in Russia in the 1970 s.

Conventional induction glass melters rely on an inductively heated metal-crucible that heats and melts glass by thermal conduction. By breaking the crucible up into isolated

- vertical sectors, cooling the sectors, and increasing the frequency of the induction signal, the glass can be directly heated by the induction field. Because the crucible is cooled on the exterior surface, a layer of cooled glass protects the crucible from corrosion. This

\footnotetext{
'Letter from Leif Erickson, Director of Tank Waste Disposal Division to W.R. Wiley, Director of the Pacific Northwest Laboratory dated September 21, 1993. A copy of this letter is contained in Appendix A.
} 
protective layer allows the bulk of the melter to be run at very high temperatures such that higher glass waste loadings, production rates and melting of refractory compounds can be achieved. The principles of the CCM are explained in the papers in Appendix B. The important parameters to be controlled are the frequency of the induction signal, the electrical resistivity of the material to be heated (glass in this case), and the penetration depth of the induced currents. The smaller the CCM, the higher the induction frequency that is required. There are size limits imposed on the CCM by these parameters. Small CCMs $(<15 \mathrm{~cm})$ are difficult to heat because the required induction frequency is very high and an appropriate signal generator is required. Large CCMs are difficult to heat because the induction frequency is so low that it will not couple to the glass. The electrical resistivity of glass is strongly temperature-dependent. For this reason, the glass in a CCM must be preheated at the beginning of a run before induction heating can begin. This has been done using microwave heating or started paths.

\section{REVIEW OF LITERATURE}

The majority of the work with CCMs has been done in the area of metal melting, not glass melting. For the purposes of this report, only glass melting will be discussed. The literature on CCMs is very limited. The majority of the work done on CCMs was done by various government agencies in Russia and in France by the CEA. The CEA has published little in this area because the development has been considered proprietary. Most of the articles are either in French or Russian and contain little technical information.

\section{FRENCH LITERATURE}

3

The two French articles ${ }^{1.2}$ used for most of the information in this review are contained in Appendix B. The remainder of the information on the French CCM was gathered during a recent trip to France. A summary of the information acquired will be discussed in a later section of this report.

In the 1970s, development of a high-frequency (HF) induction melter for glass production was started in France at the CEA. The original design used direct induction heating of the glass inside a refractory chamber. This development was haited and later resumed in 1981. The design was changed and the refractory crucible was replaced by a water cooled, sectorized, steel crucible. The crucible was sectorized to so that it is not

'Cold Crucible Techniques, Report on the State of the Art in France. Prepared by CEA \& SGN for NUMATEC, Inc. May 1991.

${ }^{2}$ Sombret, Claude G. The Cold-Crucible Glass Melter. Commissariat à l'Energie Atomique France. Paper presented to Savannah River Center. May 10-11, 1993. 
heated by the HF field. Corrosion of the crucible was reduced or eliminated because the metal wall was kept below $200^{\circ} \mathrm{C}$ producing a frozen layer of glass that protected the metal. The bottom of the melter is also water cooled to prevent corrosion/melting of the crucible. The French CCM contains two bottom drains (freeze valves). One partially drains the melter during normal operation and one completely drains the melter at the end of a run. The flow of glass through the drain valves is controlled by induction heaters.

Most of the development work has been done with a $55-\mathrm{cm}$ diameter $10.24 \mathrm{~m}^{2}$ surface area) CCM. One of the papers indicates that a $1.5-\mathrm{m}$ diameter CCM could be operated, but this has not been demonstrated. One of the papers states that the CCM design is optimized to ensure better than $80 \%$ electrical efficiency. This is misleading and will be clarified in a later section of this report. Actually, the CCM is very inefficient. The $55-\mathrm{cm}$ diameter CCM has a $240 \mathrm{~kW}, 335 \mathrm{kHz}$ power supply. For this reason, the CCM is dry fed, not slurry fed. Slurry feeding the CCM would require a prohibitively large power supply because of the additional energy required to evaporate the water. This is why both the French and the Russian designs have a calciner in series with the CCM.

Several thousand hours have been logged on the French CCMs. The CCM can be operated at very high temperatures because it is a skull-type melter. The French CCM has been used to melt refractories up to $2500^{\circ} \mathrm{C}$. The maximum glass production capacity has been $25 \mathrm{~kg} / \mathrm{hr}\left(260 \mathrm{~kg} / \mathrm{hr} / \mathrm{m}^{2}\right)$ for the $35-\mathrm{cm}$ diameter CCM and $50 \mathrm{~kg} / \mathrm{hr}$ $\left(210 \mathrm{~kg} / \mathrm{hr} / \mathrm{m}^{2}\right)$ for the $55-\mathrm{cm}$ diameter CCM. The La Hague vitrification plant $(R-7)$ glass formulation has been processed at temperatures ranging from $1150^{\circ} \mathrm{C}$ to $1380^{\circ} \mathrm{C}$.

A brief patent search was conducted with the key words "cold crucible" and "glass." The French patents that were found included a 1985 patent for a CCM drain spout, a 1987 patent for the basic CCM induction heater design, and a series of international patents (1984-1993) granted to the CEA for ceramic manufacturing using the CCM. Similar patents were found for the CCM developed in the former Soviet Union. This will be discussed in the following section.

\section{RUSSIAN LITERATURE}

The Russians have developed a cold crucible melter in parallel with the French. The Russian system is usually referred to as a two-stage vitrification process. For consistency, the term CCM will be used for the Russian two-stage vitrification process in this document. The Russian literature on the CCM was even more scarce than the French literature. The best source of information was a 1991 PNL report by Don Bradley 
reviewing radioactive waste management in the USSR'. The Russians began CCM development in the 1970s. The operating principle of the Russian CCM is similar to the French CCM but the approach is different. The Russian CCM is rectangular in cross section instead of round. The Russian design uses a spray calciner in series with the CCM instead of a rotary calciner. The most complete information is on a $30 \mathrm{~kg} / \mathrm{hr}$ $\left(170 \mathrm{~kg} / \mathrm{hr} / \mathrm{m}^{2}\right)$ Russian CCM with a $0.18 \mathrm{~m}^{2}$ melt pool. This unit operates at $1760 \mathrm{kHz}$, $160 \mathrm{~kW}$ and has an temperature range of $900^{\circ} \mathrm{C}$ to $2300^{\circ} \mathrm{C}$. The Russians have tested their CCMs with several different minerals including glass.

Further information on the Russian CCM capabilities was gathered by Ben Johnson of PNL during a recent trip to Russia ${ }^{2}$. The Russians are still pursuing the CCM technology. They have several units ranging from 1-2 kg/hr to "industrial scale." They operate their nonradioactive units at the All-Union Design-Construction Scientific-Research and Technological Conglomerate (VNIPIET) in St. Petersburg. They have recently installed a radioactive CCM system in the Mayak Plant. Original conversations with the Russians indicated that this system had a capacity of roughly $100 \mathrm{~kg} / \mathrm{hr}$. Subsequent conversations with Serge Merlin of SGN indicated that the Mayak Plant has three $30 \mathrm{~kg} / \mathrm{hr} \mathrm{CCMs} \mathrm{in}$ parallel. It is not clear if the radioactive system has gone into active operation yet.

A brief patent search was conducted with the key words "cold crucible" and "glass." The patents from the former Soviet Union that were found included a 1984 patent for a fiberglass CCM crucible, a 1987 patent for a CCM refractory founding process, and a 1987 patent for the basic Russian CCM. During the literature search an article was found that briefly mentioned the use of mechanical stirring in one of their CCMs using a watercooled agitator.

\section{- INFORMATION FROM RECENT TRIP TO FRANCE}

Further information on the CCM was gathered during a recent trip to France. Mr. Antoine Jouan of CEA presented a review of the CCM on March 21, 1994. A tour of the CCM development facility at Marcoulle followed the presentation. A copy of the presentation is contained in Appendix $D$. A basic overview of the CCM concept was presented along with a description of testing that has been completed at CEA. The amount of work in this area was impressive. They have run the CCM up to $2800^{\circ} \mathrm{C}$ in a batch mode. The limitations of the CCM were also discussed. As stated earlier, the diameter of the CCM is limited by the power supply frequencies and the electrical resistivity of the material to be melted. Several questions were asked relating to the ability

\footnotetext{
'Bradley, D.J. 1991. Radioactive Waste Management in the USSR: A Review of Unclassified Sources, Volume II. PNL-7645. Pacific Northwest Laboratory, Richland, Washington.

${ }^{2}$ Trip report will be published by April 8, 1994.
} 
to liquid feed the CCM. Mr. Jouan explained that the CCM is a very inefficient evaporator. One of his slides indicated that $70 \%$ of the power from the induction coil is transferred to the glass, but only $30-40 \%$ of this energy goes to heating the glass. The rest is lost to thermal inefficiencies. That is, the overall system is only $20-30 \%$ efficient. He indicated that the CCM is only $40-50 \%$ as efficient as a conventional refractory meiter.

A later meeting was set up with Mr. Jouan of CEA and Mr. Serge Merlin of SGN to review questions that were not answered during the initial presentation. The first part of the discussion covered the maturity of the technology. Mr. Jouan provided most of the information since he did most of the CCM development. Most of the CCM testing has been done on a $55-\mathrm{cm}$ diameter melter. This unit was observed under the Atelier de Vitrification Marcoule (AVM) calciner in Marcoule on the March 21 tour. This CCM is over ten years old, has processed phosphate glasses, lead glasses, and R-7 glasses, and is still in good shape. The $55-\mathrm{cm}$ CCM produces $10-50 \mathrm{~kg} / \mathrm{hr}$ depending on the glass. It can produce $30 \mathrm{~kg} / \mathrm{hr}$ when running $\mathrm{R}-7$ glass. At higher production rates the melter is dry fed without using the calciner because the production capacity of the calciner is limited. The maximum production rate using the calciner is $20 \mathrm{~kg} / \mathrm{hr}$ of glass.

A 15-20-cm diameter CCM was tested for melting uranium oxide as part of a fast breeder reactor meltdown study. A 50-cm diameter CCM, a 20-25-cm diameter CCM, and a 35-cm diameter CCM have been developed and tested for non-nuclear uses. The 20-25$\mathrm{cm}$ CCM has a new pour valve that can be turned on and off quickly. Mr. Jouan could not elaborate on this. They currently have a $65-\mathrm{cm}$ diameter $\mathrm{CCM}$ and a $90-\mathrm{cm}$ diameter CCM under construction for commercial glass production. The largest CCM that they have tested is a $1.2 \mathrm{~m}$ diameter unit. This was only tested for one day to see if it could heat glass at its low operating frequency, $10 \mathrm{kHz}$.

CEA has not developed a small CCM $(<15 \mathrm{~cm})$ because the frequency of the induction signal would be too high. The most important parameter when operating the CCM is the resistivity of the material being melted. They are able to melt glasses with electrical resistivities between $1 \Omega-\mathrm{cm}$ and $10 \Omega-\mathrm{cm}$. Above $10 \Omega-\mathrm{cm}$ the induction frequency must be increased. For this reason the glass must be preheated at the beginning of a run to get the electrical resistivity low enough to begin induction heating. Normally this is done using a microwave heater. During the $\mathrm{UO}_{2}$ melting this was done using a tungsten heater under a vacuum.

They have not done calciner development in conjunction with the CCM development. They currently have $60 \mathrm{~L} / \mathrm{h}, 40 \mathrm{~L} / \mathrm{h}$, and $20 \mathrm{~L} / \mathrm{h}$ calciners. The Leahflash (also called (soflash) is being developed by a private company for the denitration of uranium to produce salt cake.

CEA has recently licensed SGN to market the CCM. Serge Merlin of SGN has been working with the Russians to industrialize the CCM for nuclear waste in Russia. Evidently, 
the Russians have designed and tested CCMs, but asked SGN to help industrialize the technology. They do not currently have a contract with the Russians, but plan on doing a nonradioactive test with a Russian melter later this year. The Russians currently have three CCMs installed in a radioactive facility at the Mayak plant. Each of the melters has a capacity of $30 \mathrm{~kg} / \mathrm{hr}$. Mr. Merlin did not know if the melters had gone into active operation yet. It was not clear why the Russians need SGN's help with the CCM if they have already installed melters in an active facility.

SGN is currently trying to get a contract with the Czech Republic to design a CCM for treating low-level liquid waste. The CCM would be coupled with a calciner. The negotiations are on-going but the outcome is still uncertain. CEA/SGN are currently constructing two CCMs for producing commercial glasses. They feel that they have a big future in this area.

Mr. Jouan is currently pushing to get the CCM installed in one of the La Hague vitrification plants $(R-7$ and/or T-7). He said that the CCM would be small $(25 \mathrm{~kg} / \mathrm{hr})$ and would easily fit within the existing meiter footprint. Mr. Jouan feels that the CCM would be easier to operate and would reduce the amount of solid waste produced in the plant because the melter lifetime would be much longer.

CEA has conducted volatility tests on the CCM. There was no difference between the CCM and the AVM melter when operated at the same temperature. Mr. Jouan feels that there would be a big difference at $1400^{\circ} \mathrm{C}$. He also feels that it is better to work with the R-7 glass below $1200^{\circ} \mathrm{C}$. The CCM can pour glass above $2000^{\circ} \mathrm{C}$, but designing a canister suitable for receiving materials at $2000^{\circ} \mathrm{C}$ would be difficult. CEA has tested agitating the CCM using both gas sparging and mechanical agitation at $1200^{\circ} \mathrm{C}$. Mr. Jouan would not say whether the agitator was metallic or ceramic. The mechanical agitation incireased the production rate between $1.5 \mathrm{X}$ and $2 \mathrm{X}$.

\section{DISCUSSION AND RECOMMENDATIONS}

It is safe to say that the CCM is a promising technology. Because of the lack of information, it is difficult to determine if the CCM is applicable to the Hanford HLW vitrification plant. Several uncertainties exist:

Is a calciner compatible with the Hanford waste? Calciners were previously investigated for HLW vitrification in the U.S. Spray calciners have difficulties with particulate carryover and on-line efficiency. The Hanford tank waste is alkaline and has a high sodium content. This type of waste has conventionally been difficult to treat in rotary calciners. Low melting alkalis and mastic phases form in rotary calciners that can lead to clumping and clogging. 
- Will operation of the calciner/CCM lead to unacceptable off gases that will adversely affect the rest of the off gas system? This includes both volatilization and particulate carryover.

- Can the CCM achieve high processing rates with Hanford feed? How many CCMs will need to be run in parallel to meet the processing requirements of the HLW vitrification plant?

- Is the CCM stable enough to be used in a remote environment?

- Is the residence time of the CCM sufficient to ensure proper dissolution and mixing of the glass? What is the quality of the giass produced by the CCM?

- Will glass spall off of the cold wall and "contaminate" the glass product?

Because of the demonstrated capabilities of the CCM, it is difficult if not impossible to discount its applicability to the Hanford HLW vitrification plant. It is the opinion of the author that a proof-of-principle test should be conducted using Hanford feed on a complete CCM system (feed system, calciner, CCM, dust scrubber, etc.). This could either be done at the Marcoule test facility in France or at the VNIPIET test facility in St. Petersburg, Russia. The current direction from $R L$ favors doing the testing in France. The testing should entail, but not be limited to the following:

- The test system should be complete (feed system, calciner, CCM, and off gas system) and properly sized. The calciner should be slightly oversized such that the maximum production rate of the CCM can be determined (the current calciner on the 55-cm diameter CCM at Marcoule in undersized such that the CCM is normally dry fepd). The CCM should be of sufficient size such that the people conducting the test can combine the test results with their previous experience to make a rough estimation of full-scale plant requirements.

- Hanford feed simulant (either NCAW or the current undefined blend composition) should be used for the test. This should include all of the problem compounds such as sulphate, chloride, nitrates, etc. The people conducting the test would be free . to modify the simulant with additives. (e.g., acidify or add sugar) provided that they also address the consequences (e.g., removing the $\mathrm{NO}_{x}$ from the off gas).

- The people conducting the test will be free to either use the Hanford glass composition or develop their own composition, as long as the waste composition is not altered and durability specifications are met. This will allow maximization of the waste loading.

Testing should be conducted for a long enough time to allow the system operation 
to be properiy evaluated. This is estimated to be three to seven days.

- Product samples should be taken and analyzed for homogeneity, chemical durability, and undissolved phases.

- Decontamination factors for each major piece of equipment should be determined.

- Pre- and Post-test equipment examinations should be conducted to detect any corrosion or clogging problems.

It may be prudent to wait until the August/September time framie to sign a subcontract for CCM testing. This would allow verification by the independent technical review group working on the HLW melter selection effort that the recommendation made here (to go forward with an initial CCM performance test) is consistent with the overall TWRS HLW strategy. However, if testing of a CCM is going to go forward, the subcontract must be signed in FY 1994 so existing funds can be utilized since FY 1995 funds are limited. 


\section{APPENDIX A}

LETTER FROM LEIF ERICKSON TO W.R. WILEY

$c^{3}$ 


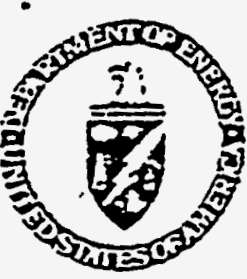

Contractors

Richland, Hashington

President

Westinghouse Hanford Company

Director

Pacific Northwest Laboratory

\section{Department of Energy}

Ricinane Coeracisas Of:"s:

7.0. 30x $\equiv$

Richland. Wasring:zs 99352

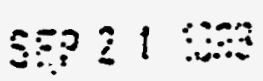

Gentiemen:

TAWK WASTE REMEDIATION SYSTEM (TNRS) FOREIEN TEGHNOLOGY COLLABORATION FOR FISCAL YEAR 1QQ4.

The following technological arazs and activities should be considered for funding during F'? 1994. The exact scope and nature of the testing proctins nesd to be considered within the context of the TaRS New Tecinnical Strategy. ine objective is to identify potential arsas of ioreign eoliaboration for prioritization with other identified iasks.

\section{HIGH-LEIEL HASTE IMMOBILIIATION}

1. Consjder the Frenci "Cold Crucibla" Meitar (CCM) as a candicata "next: genefation" meltar and evaluata with other likaiy technologies, such as the "stirred" and "high temperature" welters. If the ccy has merit then consider the following:

- A) Conduct vitrification tests in the French "Coid Cruciole" Me? tar (CCM) system using simulated itaniord Tank wastes. This incluces calcining the waste prior to vitrification using the "LEAFl-ASit" technology. This work will be conducted at Marcoule throughin Comissariat Energy Atomic (CEA).

8) Initiate dialogue with the Franch to purchasa and install a CCY system within the 324 building (CEA).

2. Investigate implementing the CCy as the vitrificztion systam for the Initial Pretreatment Hodule (IPH) hot pilot plant operation.

3. Eyaluata the CCM system as a candidata technology for satisiying the HWVP " 4 " seenario. This work will be conductad through collaberation with SGN. 
4. Continue discussions with the French concerning capabilities, acquisition, and licensing of the liquid transport system (LR-5o).

\section{PRETREATMENT}

1. Continue collaboration with the French on the "Oiamex" and "Cai ixarene" processes as well as other potentially beneficial processes for the separation of chenical species.

\section{LOH-LEYEL WASTE IMMOBILIZATION}

1. Initiata dialogue with the British (British Nuclear Fueis Limitad-BNFL) regarding grout waste formulation, product and process control, and performancs assessment modeling. The intant is to design an improved low-level wasta form and evaluate periormanca for the regulators.

This list is neither comprehensive nor esmplete, but is intencisd to highlignt potential areas of collaboration identified by the THRS tacinology tain during their visit to French and British facilities durine july loga. Please contact Steva Burnum of my stafi, on 375-8409, for aditional datails.

\section{TRB:STR:}

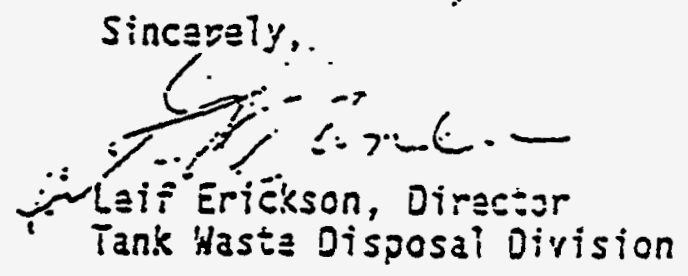
ce: D. Hyane, EH-36
J. Crear, HHC
T. Neber, WHC
D. Hodrich, MHC
S. Senaus, MHC
H. Miller, whic
J. Voogd, KHC
R. Murkowski, WHC
R. Kirkbride, WitC
S. Barker, WHC
J. Appel, iHC
G. Hansrote, WHC
W. Apley, PNL
J. Hestik, PNL
G. Lumetta, PNL
G. Beeman, PNL 
APPENDIX B

FRENCH LITERATURE EXPLAINING COLD CRUCIBLE CONCEPT r.? 


\title{
The Cold-Crucible Glass Melter
}

\author{
Claude G. Sombret \\ Commissariat 2 l' Energie Atomique \\ France
}

May 10-i1. 1993 


\section{INTRODUCTION}

The vitrification process currently implemented in France to solidfy concentrated fission product solutions uses melters in which the heat source is an induction-heated metal chamber. This process meets the requirements of the French and English reprocessing plants, but does not allow melting at temperatures above $1200^{\circ} \mathrm{C}$.

In the 1970s, advantages were perceived in developing a facility with a larger throughput capacity, capable of achieving higher melting temperatures. A heating process was developed implementing direct induction in the glass inside a refractory chamber. The development of this process was intermuted in the late 1970 s to meet the workload arising from commissioning of the Marcoule Virrification Facility (AVM) and from the UP3 and UP2/800 reprocessing plant projects with their two vitification units, $R 7$ and $T 7$.

A direct induction process using a water-cooled metal crucible was developed in 1980 to melt metal waste. The experience acquired made it possibie to consider renewed development of the direct induction glass melting process beginning in 1981, but with a water-cooled sectorized metal crucible instead of the initial hot refractory crucible. The new process not only allows fabrication of high-sillica glass and eliminates crucible corrosion problems, but also considerably increases the melter capacity without increasing the overall dimensions of the facility.

\section{OPERATING PRINCIPLE}

The glass is fabricated and melted in a generally cylindrical, water-cooled metal cracible. The glass in contact with the cooled wall solidifies so a depth of a few millimeters, as the wall remperänure does not exceed $200^{\circ} \mathrm{C}$. The botrom of the curcible is also 3 water-cooled metal plate, so the glass is fully contained in a solid glass "crust", heace the term "skull melting".

- The crucible is surrounded by the coils of an induc:or supplied with a high-frequency alternating current, which induces curreats in the molten glass that dissipare bear by Joule effect (the resistivity of molten glass is a few $\Omega \cdot c m$ ). In order to ensure suimble electrical efficiency when transferring power from the inductor wo the meit, the frequency must be determined so the peactration depth of the inducod currents in the glass is less than the crucible radius. The peneration is given by the following relation:

$$
p=\sqrt{\frac{\rho}{\text { sq }_{0} H_{2} F}}
$$

where $p$ is the penetracion depth in meters, $p$ the glass resiscivity in $\Omega \cdot m, \mu_{0}$ the magnecic permeability of empty space $\left(4 \pi \times 10^{-7} \mathrm{H} \cdot \mathrm{m}^{-1}\right)$, $H_{4}$ the relative magnecic permesbility of the glass and $F$ the inducror frequency in $\mathrm{Hz}$. The following simplified formula is geaerally used:

$$
p=503 \sqrt{\frac{p}{F}}
$$


The metal crucible containing the glass must be sectorized to ensure relative transparency to the electromagnecic field generated by the inductor; otherwise, it would constinute a Faraday cage, preventing the formation of induction currents to heat the glass. The power density transmitted to the glass decreases to zero from the wall to the center of the melt. This gradient provides for convecrive stirring within the molten glass. The glass level rises along the wall and diminishes in the center of the crucible. There is no electromagnetic stiring effect, since the electromagnetic fores are one or two orders of magnitude lower than those generated by the thermal gradient.

\section{DESCRIPTION}

A direct-induccion glass melting facility comprises four subsystems:

- a water-cooled sectorized cold crucible;

- a crucible bottom structure supporing the glass casting nozzle;

- a high-frequency generator, inductor and uimming capacitors;

- a glass preheating system required on startup, since cold glass is a poor conductor and must be preheated unil the energy transmitted by inducrion exceeds the thermal losses.

\section{Cold Crucible}

The crucible (Figure 1 ) is an assembly of stainiess sieel sectors foming a cylindrical structure. Typical crucibles are $0.55 \mathrm{~m}$ in diameter and $0.70 \mathrm{~m}$ high. although the actual dimeasions may be smaller or larger (e.g. $1.50 \mathrm{~m}$ diameter). A three-dimensional computer model is used to opcimize the dimensions and ensure better than $80 \%$ electrical eiñciency. Each sector has a rectangular cross secion, and includes water ports mating with the iniet and outlet. manifold"s. The sectors are separated trom one another by electrically insulating material. The structure is mainained externally by strapping with refractory fabric.

\section{Crucible Bottom Structure}

The cold crucible is supported by a botwom stucture comprising a warer-cooled seainless steel ceater plate and a refractory cement outer ring. The reiractory assembly is molded to allow bandling. Water cooling of the center plate and crucible wails is sufficient wo solidify the giass in coneact with the retractory ring, forming $a$ continuous layer around the melt The ceater plate supports the following elemeats:

- a casting nozzie exteading into the melt. designed to reain a sufficient glass heel to allow continued induction afeer casting; it comprises either a glass freeze valve controlled by a medium-frequency inductor, or a separate mesbanical shutter.

- a drain nozale with an induction-heated freeze valve at the botrom of the crucible to empty the glass beel:

- air or argon injectors exiending into ine meit to ensure themal and chemical homogeneity by sciring if necessary. 


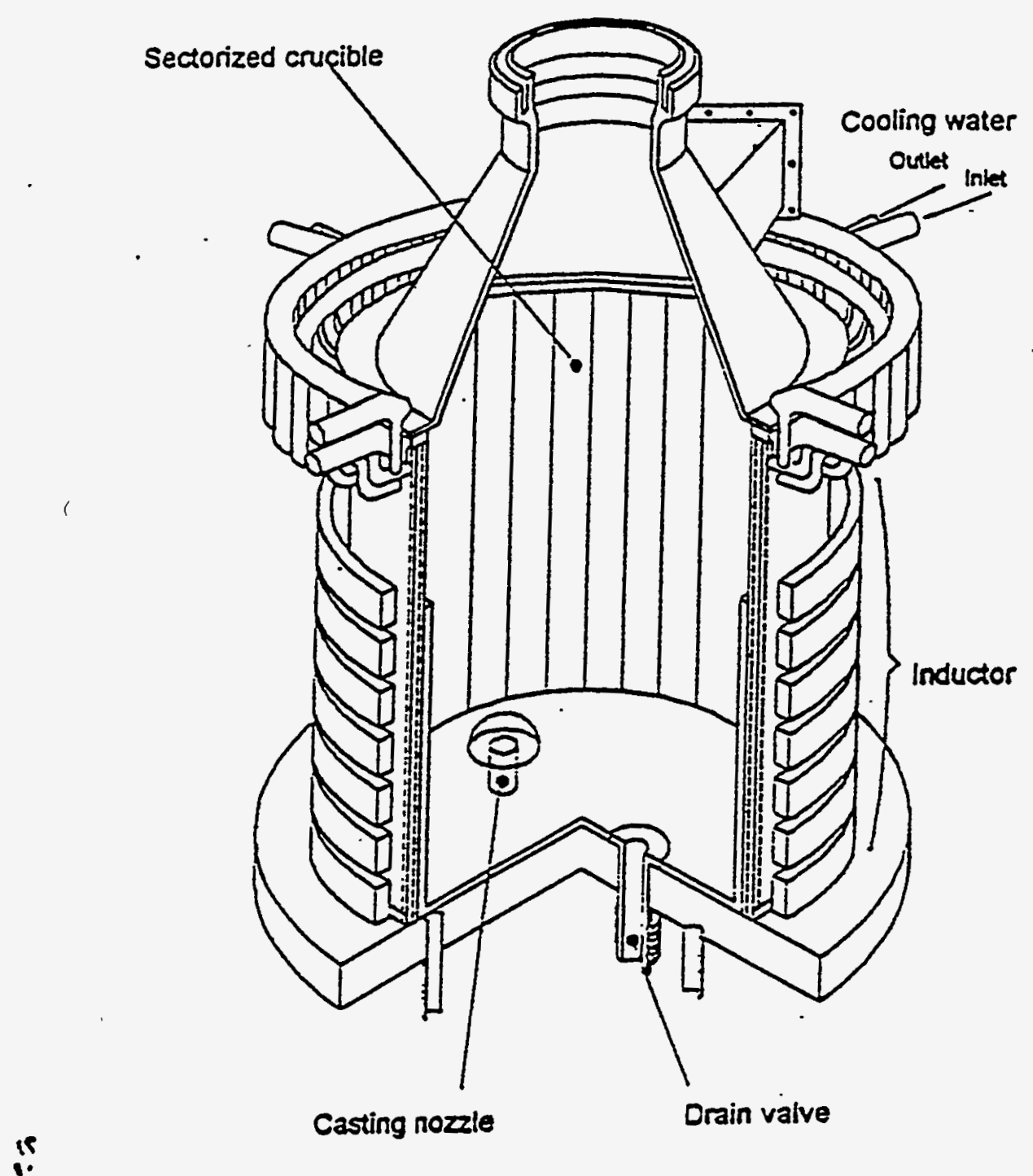

Figure 1. French Cold-Cruciöle Melter

\section{High-Frequency Generator}

A vacuum tube generator with three shuned triodes supplies $240 \mathrm{~kW}$ at $12000 \mathrm{~V}$ at 2 frequency of $335 \mathrm{kiz} z$ for a crucible $0.55 \mathrm{~m}$ in diameter. A bigh-frequency line consisting of two warer-cooled copper sections conneces the geaerator to a multiple-winding inductor placed around the cold curcible. The geomerry of the oscillating circuit and the distribution of the trimming eapacitors ensure a aull potencial berween the cold crucible - containing the molten glass - and earh, making additional insulation unnecessary berween the crucible and its supporting strucsure.

\section{Preheating System}

Various rethods were considered, inciuding expendable or scoversble juscepters. 1 heated

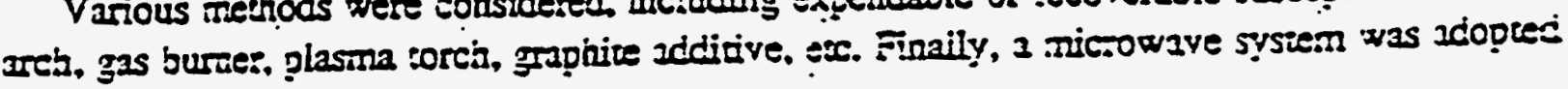


because it allows energy to. be transmitted to the cold glass without contach and without sequiring placement of the generator in the shielded cell containing the melter: no mechanical or electronic components of unproven reliability are therefore located inside the cell. 7.2

Most of the cold crucibles implemented to date have used a $25 \mathrm{~kW}$ microwave generator operating at a frequency of 91501H2. transmitting energy to the melter via a rectangular wayeguide with inside dimensions of $124 \times 248 \mathrm{~mm}$. The waveguide is connected to the tapered upper junccion between the melter and the calciner, a quartz window on the melter end ensures a leakright seal.

\section{ADVANTAGES}

The process ayoids any contact between molten glass and the cold metal wall, thereby preventing crucible wear regardless of the glass temperature or the melt composition. This type of crucible has successfully been used to melt $\mathrm{UO}_{2}$ at $2500^{\circ} \mathrm{C}$

Not only is corrosion eliminated, but the energy input to the glass is unlimited, allowing high produccion rates. The glass melting iemperanure may easily be raised above $1200^{\circ} \mathrm{C}$ if necessary.

\section{PERFORMANCE}

Several thousand hours of iests have been conducted to date with meiters $0.35,0.55$ and $1.20 \mathrm{~m}$ in diameter, supplied with ground glass, or with glass and calcinate (either premixed or with the meiter coupled to a calciner of the same rype used in the $R 7$ vitriffeation facility), and, at temperaures ranging from 1150 to $1380^{\circ} \mathrm{C}$. Toe maximum capacity has bean about $25 \mathrm{~kg} \cdot \mathrm{h}^{\circ}$ For the $0.35 \mathrm{rm}$ diameter melter, and $50 \mathrm{sg} \cdot \mathrm{h} \cdot \mathrm{l}$ for the $0.53 \mathrm{~m}$ diameter melter. The acrual throughput depends not only on the melter diameter, but also on the temperanse. At $1300^{\circ} \mathrm{C}$, a melter 1 meter in dianceter ean produce $200 \mathrm{~kg}$ of glass per hour when supplied with dry material. .. Testing with liquid feed resulted in 3 lower capacity, and raised some cechnological problems.

\section{ARPLICATIONS}

In addition to melting mecal waste, the high capacity and high temperanre capability of the cold crucible melter are comparible with many appiications in the area of radioactive waste vitrification: concentrated fission product solutions. Low- and incermediate-level solutions with vitrifiable compositions, and solid inorganic waste that is either unfit for incineracion or for which incineration would produce 3 hererogeneous ash/oxide mixure and a low volume reduccion racio (e.g. restoracion of concaminated soils).

Among other projects. the French are now building a vinification facility for low-level radioactive liquid waste from the Temelin power smion in the Czech Republic. A tull-seale procotype unit with a cold crucibie $0.50 \mathrm{~m}$ in diameser will begin opersing $3 t$ ihe site in $: 994$. 


\section{COLD CRUCIBLE TECHNIQUES}

$$
\begin{aligned}
& \text { XC: Jousen } \\
& P_{t a n}=2 \\
& \begin{array}{l}
\text { Elliatt } \\
W=s t s i t
\end{array}
\end{aligned}
$$

REPORT

on

\section{THE STATE OF THE ART}

in France

Prepared by CEA \& SGYY

for NUMLATEC, Inc. 


\section{THE COLD CRUCIBLE TECHNIQUE}

\section{GENERAI}

Several operations for the treameal of iadioactive wastes involved high tence:ante itemal processing, for instance in view of emicedding IIW in a glass matrix or susing metallic 'zastes ior jeciucing their volume or even high iemperanure cracking ot organic compounds. Tness operations are traditionally earried out in conyentional ovens or innaces, but dintiesities in operation may arise in aciount of the temererantes iequired and the aature of the materials in eontact. Taese diffecrities cannol always ie overcome in a satisiactory manner, the more so witen operaring concitions which would reduce these ciifisculties are conrlicring with process reguirements: in some instances, it would be desirable to decrease be iemperature to iecuce the corrosion of the cusciole and increasse its WT3F, but a lowe: ienceraruse would zor yield the desired oroduct characiesistics.

\section{- PRNNCIPLES OF THE COLD CRUCTBLE}

The :esocesante level berwees the material io be healed and the sorciole may be sigrifieandy seduced if the bear lun does not have to be wansmired through the wail of the creible and if the wail of the cosciole is cooled. 
This may be acsomplisined oy an 3ẹproprinte tearing of the rabtesial in the bulk

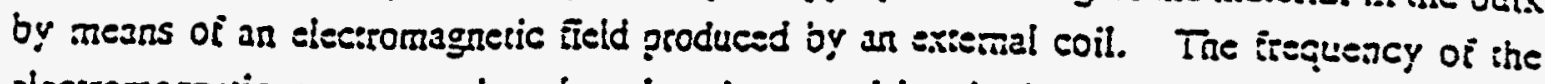
electromagnetic wave must be acapted to the rnaterial to be heated for an erisicieat sasegy coupling. Quite low, trom 1 to $10 \mathrm{kthz}$, when wetals are concersed, much higiner, 100 to 500 $\mathrm{kHz}$ in the cass of glass or dielectric materials. If the wuciole is anade in a aon-concuctive material or mace of narrow and insulared metallic strips, it is ranspareas to the electromagneric iield and should iemain cool.

However, the heated mass in the eanter will conduct and radiate ineat iowarcis the outside, and to preveat the temperanure of the ruscible for incieasing ioo anuch, the metallic strips constiwting it are cooled (Fig 1), geaerally by water ansing ihrougi channels within the strips or through copper tubes welded outside (Fig 2).

Under these ciresmstances, the material directly in contact with the cooled cacible solidifies. As a result, the molten material comes only in contact with solid material of the same composition, and risks of corrosion of the Guciole as we!l as the subsequeat contamination of the tacility and eavironmeat are greatly iecuced. Also, when producing matesials with sxacing spesiñcations, the desired grcouct does soc come in contac: with ioreign compouncs and maineains a high degres of purity.

Tre thoice of the Iseguency of the slectromagne?ic wave is very important as it bears direc:ly on ibe jower eficieacy of ite process.

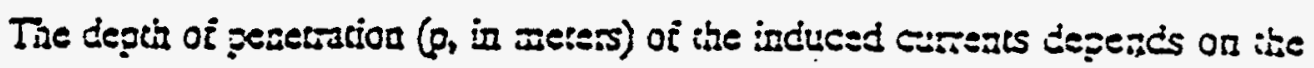

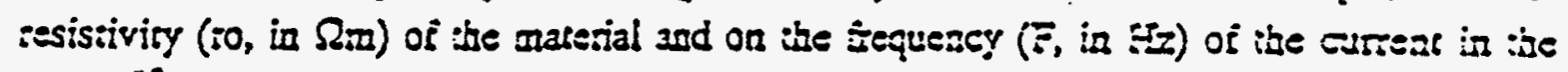

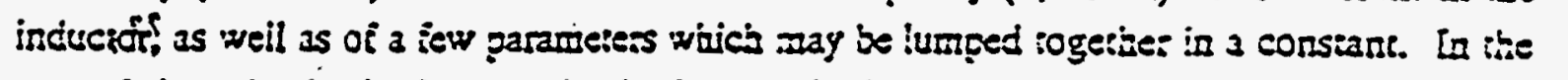
cass of glass, the depeth of pezetration is given by the formula:

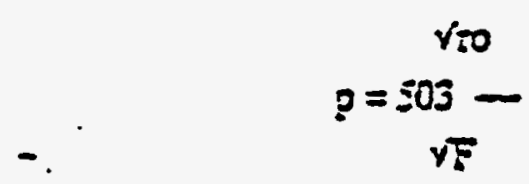

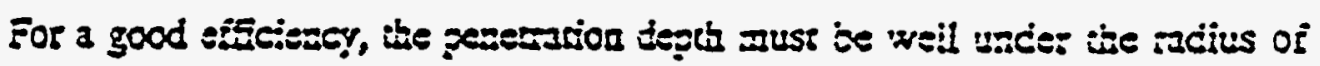

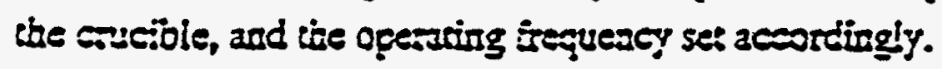




\section{COLD CRUUCIBLE EXPERIENCE AT CEA}

The cold curciole tecinnique is tnecer development and :esting at. Warcoule since 1981. Since that ime, it ias been sẹlied sicesssiully at various senles, up to the industrial scale, to çuite diverse prooblems.

The inst develogment concesaed the melting of iulls irom reprocessing. The process has besa qualified both at ine indussial level and on the sadioactive standeoinc through the ocesarion of two facilities:

-nirstly, an industrial size iacility juilt in Marcoule and commissionned in 1983. Twenty tons of stainless steel and zirealoy jave been processed suceessistly into one meter long ingoes in this iacility.

-secondly, adioactive stainless steel isulls from the reprocessing of breeder Erels have besa cold cucible melted in a smaller iacility housed in a hor cell. A high aceson!amination accor has been aoced, saabiing the ingors to comoly rery likely with subsuriace storage saecinications. Tue c--ontasination is essentially dissolved in the Iur, and may se suosegueatly vitritied.

Ancthe: açolication sorcins 3 large capacity giass melting furnace jased on

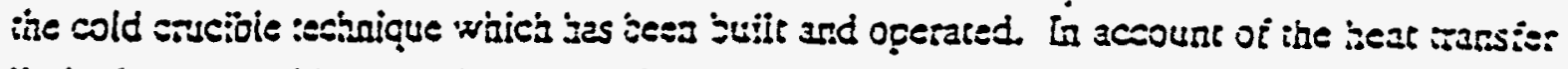

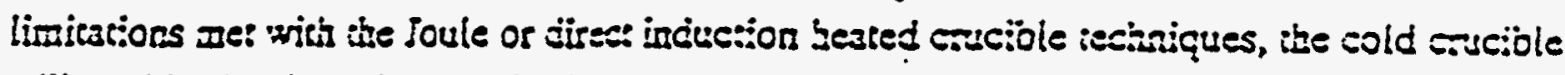
will enable the ibroughout to be ircreased, the temperantre of the glass to be raised tor a

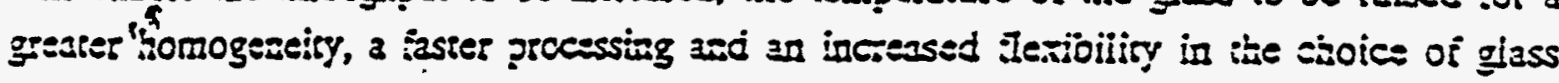

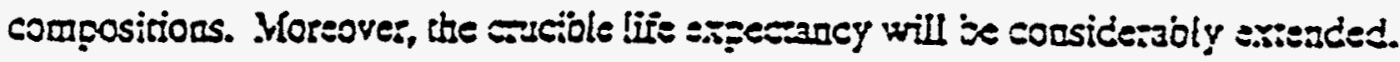

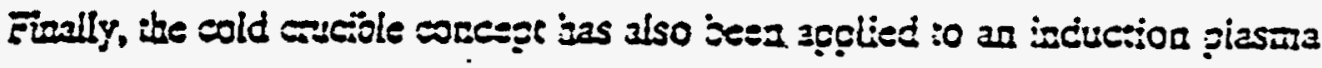

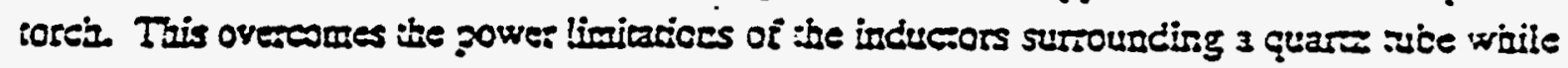
prodveing a plaswa wich a lower velocity, 3 raluable asset.

Comeared to conveational infraces or overs, the sold Escibie :ecijniçue jas aiso the tremeacious advantage of jariag =ost of the zraintainable =quiponeat :eraved from

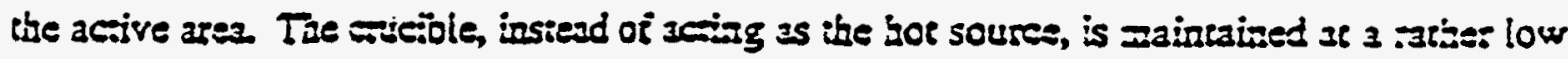

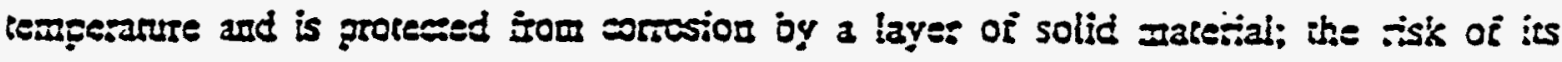

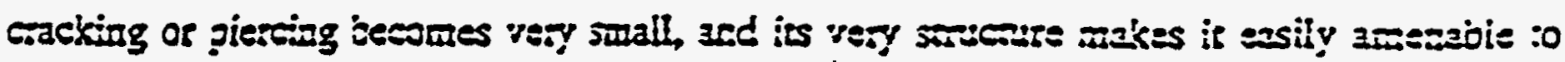

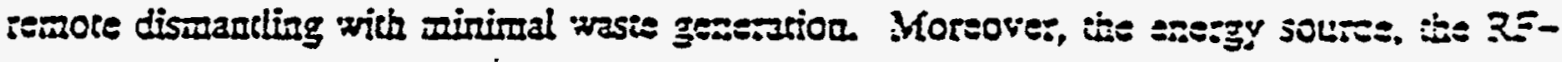

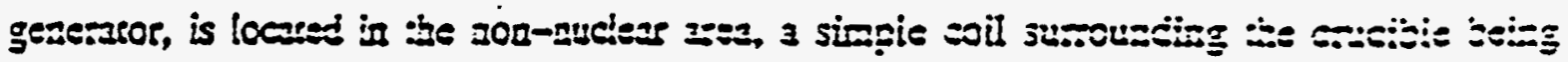
locared in ite tor sell arez 


\section{FROM REPROCESSING HULIS TO INGOTS}

Several schemes have been conceived in the past tor the processing of the huils issued irom the dissolution step of suent ituel teprocessing. Hulls are "empty she!ls" but still contain a residual, essentially alpha plus bigh level beta-ganma contamination, with isces of tritum and Ki-35 when originating trom !ight water reactors. Fuel cladding material is stainless sieel in the case of breecier teactors, and zircaloy, with a small percentage of stainless . and inconel, in the case of LWRs.

The most straighriorward packaging method is emoedding ibe hulls in a conciete marrix, but the gain in volume is nil, a disadvantage whenever deep undrground disposal is contemplated. A teduction in volume may be ootained by first compacting the bulls, then enoedding them in a metallic matrix such as lead.

However, the greatest reduction in rolume is obtained by fusion of the bulls. Conveztional metallurgical techniques seem inapopropriate in accourt of the iadioactivity of the processed material. On the contrary, the cold erucible iechnique exhioits many acvantages: these is no transier of material in the melt, the ingor is contisuously fed with scrap material until it :eacies its unal size, and the use of a flux prereats ithe oxidation of the wetal. removes surisce oxjdes and contanination. Tue process is also sasily amezaile to semoce oce:ation and maintenance. These seasons !ed CEA to the tesign and construction of several tacilities to test and gavaliigy this process at ibe incustrial seale:

Firstly, an inciusarial seale taciility, istly auclearized, esabling ingoes $200 \mathrm{~mm}$ in diame:ffiand $10 \mathrm{CO}$ mm in leageh io be cast semi-continuously hes beez built in . Warcoule. A rug sazbles some 200 to $250 \mathrm{~kg}$ ot wastes to be jrocessed, witb a power :equirssaest of 4 io 6

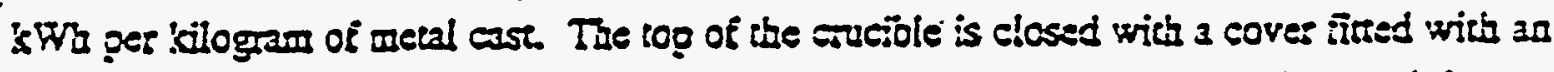
- infle: jort througi which a metered jow of julls is inroduced, an inlet wice ior sueplying an

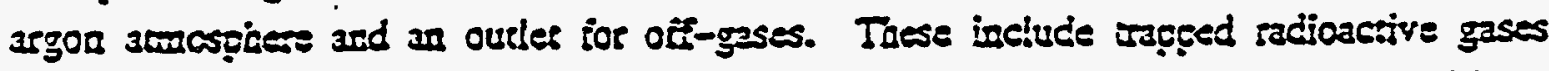
reieased during the melting of the juils. Af the borrom, the wuciole (Fig 3 ) is slosed by 3 wase: sooled novieg plase.

At the beginning of a sun, the moving plate is brought Inusin with the botiom of the incuceor, bulls are iet into the cuscioie and the inducior is veergized. Fur introduction is aeceorioned to the bull jeed aste. More julls are ied into the cascible uncil the retal iescies a preser level witere pulling down of the ingor is iniciated. More bulls are xeetersd ineo the

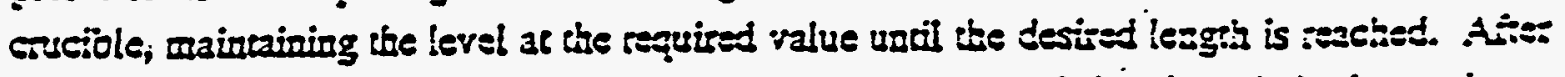

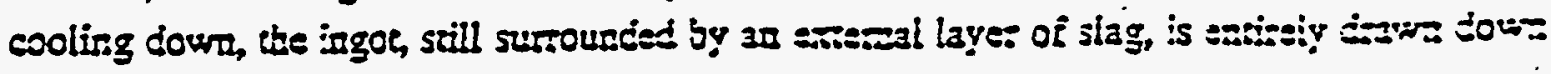




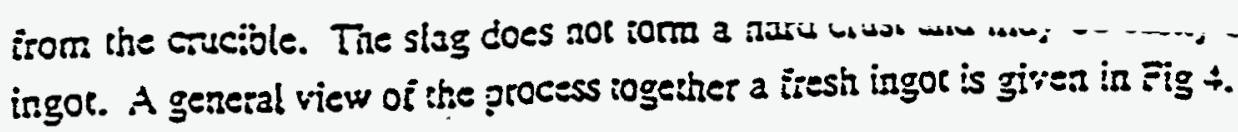

The initial melting capability of $40 \mathrm{~kg}$ per hour may je essily coosied io $100 \mathrm{~kg}$ pe: hour. Tests were caried out on stainiess steel hulls and 17 ions have been processed so far. Some 3 cons of Zircalloy bulls bave also been cast. Based on the initial rolume of the aulls, the compac:ion iac:or is sizezole, and the suriace area ieducition of the orde: of 300 , lowering signiricancly the risks to the eavironment associated with !riviation, aot to mention the dectease in the amount of adioactivity coneaised through ine combised action of iusion and fluxing.

Secondly, a small size hor iacility located in Warcoule and housed in a heary concrete cell has been commissioned in 1988 (Fig $\Sigma$ and 0 ). Siainless sieel hulls, originating from the reprocessing of the Phénix tast breeder reacior iusel, have been processed very successiully yielding small ingots (5ig 7$)$. These weigh around 2.5 to $3 \mathrm{~kg}$, with a anominal diameter of $60 \mathrm{~mm}$ and a length of 130 :0, $180 \mathrm{~mm}$.

Daca show inat nosi of ihe c-activity has concentsated in the slag originating from the blux used in the oceration. The iesulting stag may ce very easily separared irom the ingor and iurhermore, te encecided by ritrification. Tesis earried out on Zïealloy aulls show a lesser degres of deconumination. This is litele surprising on acsount of the seducing powse of zisconium: some oxides from the lulls, ooce they iave been iscuced, are grevested from nigating into the Jux. Fiux ionulation (oxides and fuorides) is jeing optimized so as :o acinieve ihe jigines: decontamination isctor. 


\begin{tabular}{|c|c|c|c|}
\hline \multicolumn{4}{|c|}{ FLUX PERFORULAYCES } \\
\hline \multirow[t]{2}{*}{ Cladding } & \multirow{2}{*}{ Fiux iormula } & \multicolumn{2}{|c|}{ Decontamination Ëзc:or :or } \\
\hline & & $a$ & beti-gansma \\
\hline Sizinless & 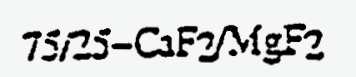 & $\geq 99,5 \%$ & $\approx 11 \%$ \\
\hline Zircalloy & $50 / 50-\operatorname{CaF} 2 / B a F 2$ & : Y.A. & N.... \\
\hline
\end{tabular}

\section{VITRIFICATION}

Tize vitrification process developed by CEt and opeated by COGEVhA in La

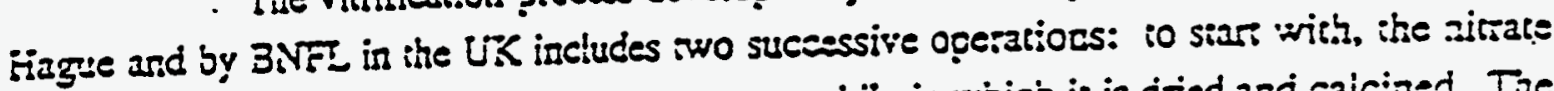

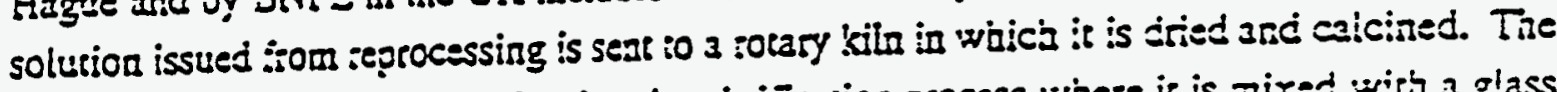

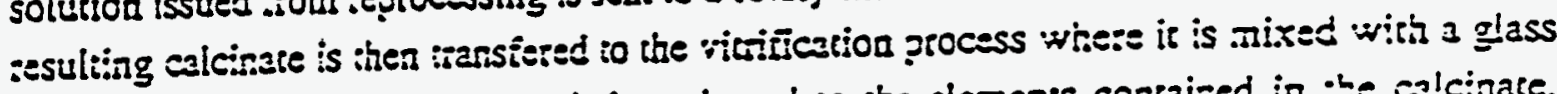
Eith, 3 primary glass with a jormularion adapted to the elements contained in the calcinate, designed io obtain acequare geriomances with respees :o lixiviation of the itaisied produce.

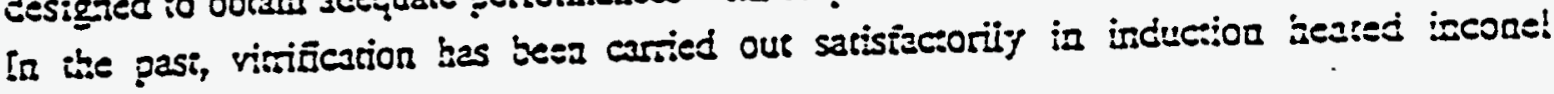
crscioles.

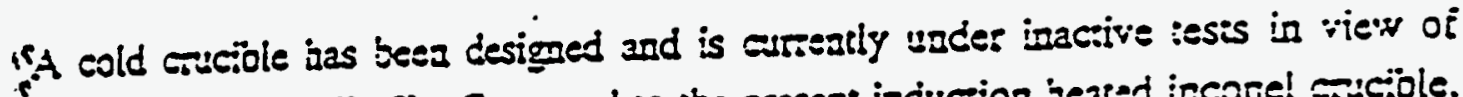
surure virrification units (Fig 3). Compared to the present incue:on jeated incore! saceiole,

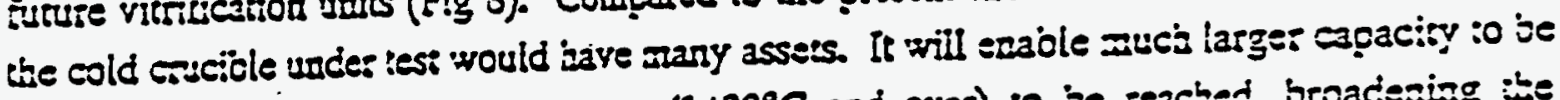

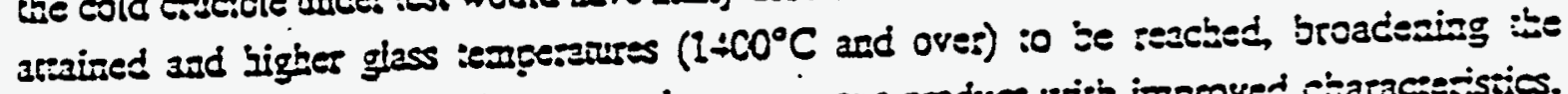

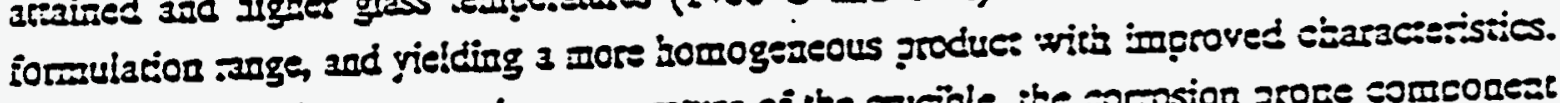

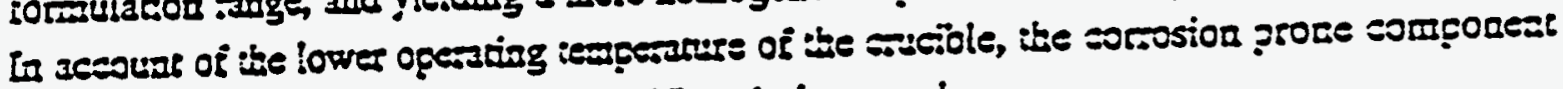

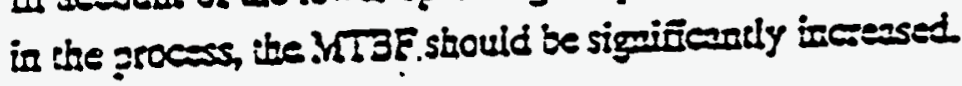

Cperang concitions difier widely wibether it is wetal or giass ibat is processed

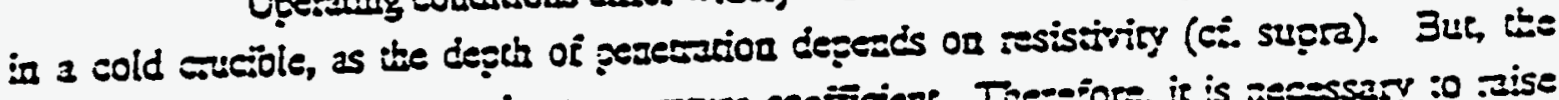

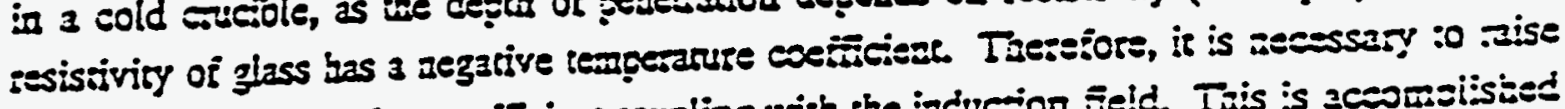

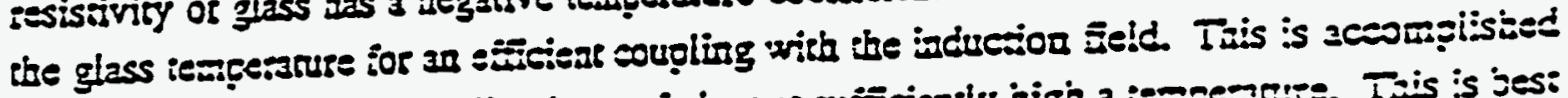

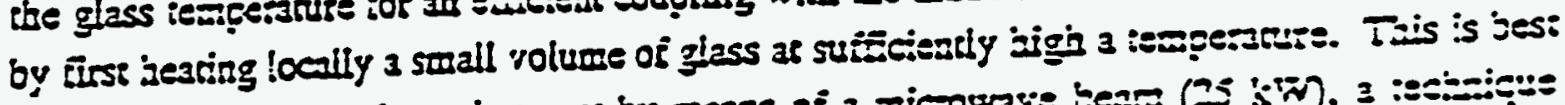

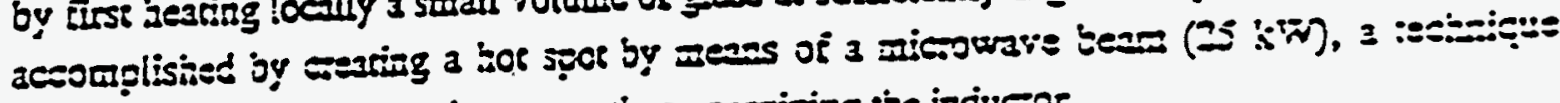

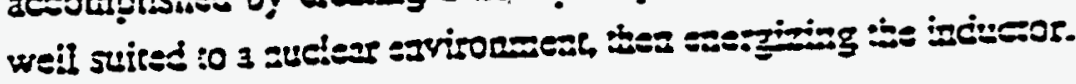


Thanks io a 3-D model developed jointly by the . KAD YLAWh laboratory of ihe Iational Polyrecinic Institure in Grenoble and CEA, it is possiole to optinize the dimensions and design of the cold crucioles ior glass melting. Taus, power eîñciencies in excess of s0\% an be achieved.

With a crucible $55 \mathrm{~cm}$ in diameter, it is possiole to me!t $50 \mathrm{~kg}$ of glass per hour. Incseasing the diameter up $10100 \mathrm{~cm}$ will increase the capacity up to $200 \mathrm{igg}$ per bour at its least, a value cohereas with the eutreat througingut of ieprocessing plants. Today, only reizaciory insmaces with elecirode hesting atrain such copacities. But they are very bulk:;, their. WTBF ratiner low and very costly to dispose of once contaninated. On the contrary, cold crucibles an be ieacilly dismantled and decontaminated: solid glass does not achere to stainless siest, and the decontamination of stainiess is routine. A one meter diameter cold cruciole has been built and tesied at CEA. lts larger dimensions enable the inducior to operate at 10 to $50 \mathrm{kizz}$ ocening the way to solid state aigh power supplies.

With process optimization in view, the beneivts of processing a nitric solution siraight from reprocessing versus a ealcinate teed is under study. With a cold cuciole, the power incossse resuiting from such a change in the process flowsizes: would not aave any

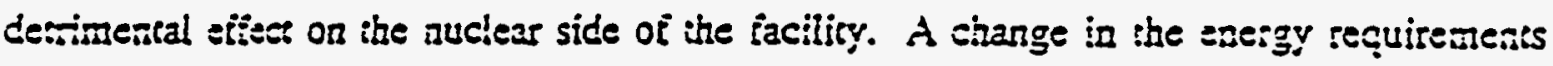
would only concers the water cooled soils located just outsice :the saciciole, and, of course, ithe sower supply !ocared outside the auclear arez.

Virisication :rould then beenase a prsien:ed gackaging process, nor only for GIN, bur oor.MLW and LIW as reell.

\section{PLASMA TORCE}

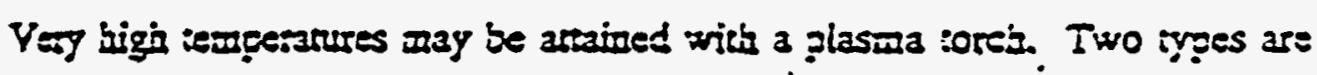
curseady is use: ihe ure induced piasma, and the inducsively coupled plasua. Higine: powe:

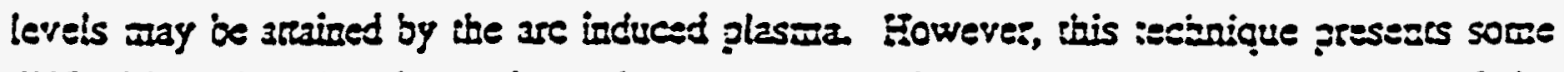
dificulties winea the plasma is used io erack sorosive gases and vapors: iajlure of ite elestodes, geseral corrosion.

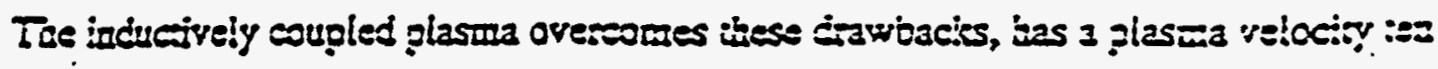

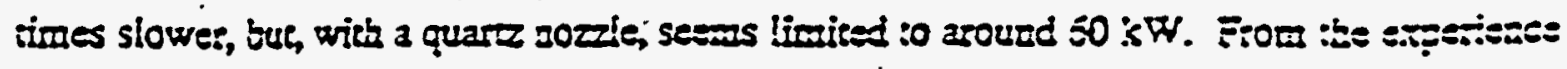

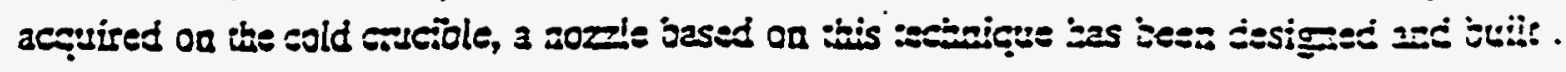

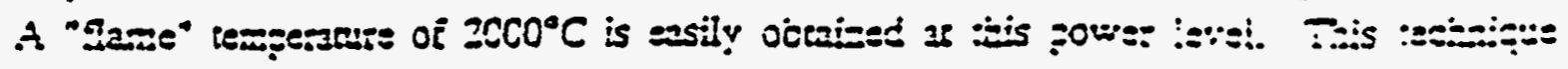




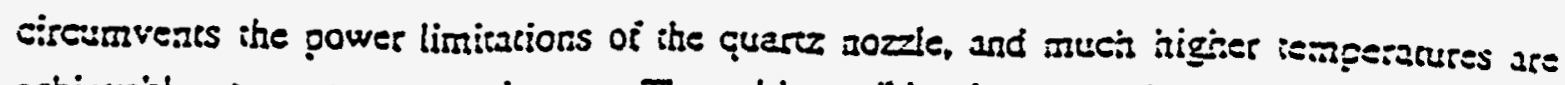
achievable at greater power inguts. The cold wuciole plasma iorsis iechniçue sinould ind applications in many areas, and in particular io the buming of the otf-gases procuced during the calcination of organic bearing naterials even when nigifly corrosive.

\section{MISCELLANVEUS APPLICATIONS}

The cold rouciole rechnique, ibe mose it is krown, the nore versatile it prostes. Its characieristies have opened many areas in the quclear ijeld, in the processing of wastes in particular. It should tind many applicarions for the processing of difficult or aoxious or highly corrosive compouncs. This iechnique being well mastered by CEA for a nuclear eavironnent, it is available ior solving perding guestions.

For instance, asbesios which ias jean widely used in lagging and iirs procection until recear years, presents an unacespeable bezlin zazard and siould be dispeosed or proces:ly. its

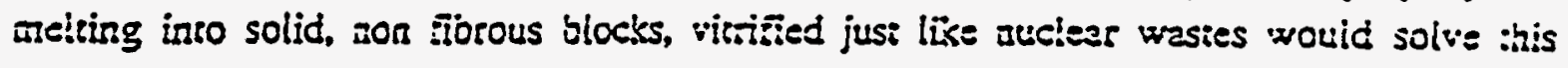
proolem once and iorever.

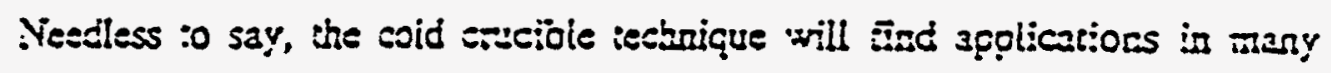

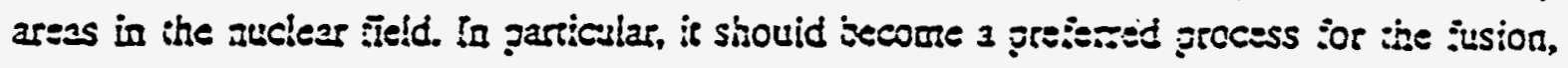

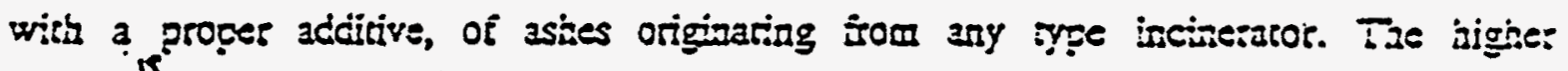

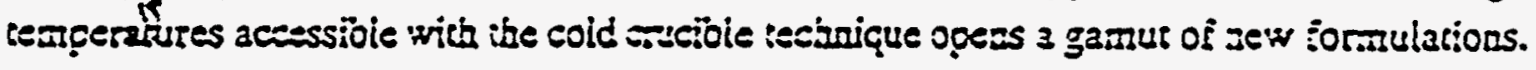

Sçecial glass zanuizcaress stow great interest in ite cold Excioic teciniçue

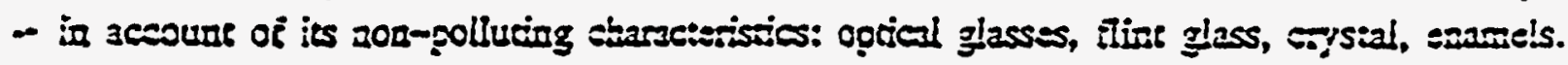

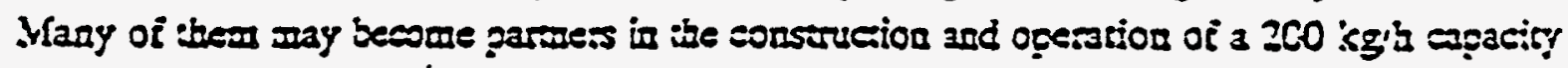
"vitioñcation" bacility in a sear tuturs. 


\section{FUTURE DEVELOP:YENTS}

The cold cucioie tecinnigue shows signifreant advantages over conventional techniques insolat as no wear ocesss in the vicinity of the materials to be processed as it is the case with joule heated or other conventional bor crscible tecinniques. Tnis regresents a tremencous asset in the nuclear field whe:e maintenance is a refy heawy and cosily operation. Tinere is no enciole to corrode, there is no resistor to kail, these is no bulky equuipment to dispose of in the end.

The experieace gained by scientists and iecinicians in Marcoule suggesis a bright future for the whole of this techrology held by the DCC, (Direstion du Cycle du Combustible) the Fuel Cycle Direction of CEA and developed in elose cooperation with French industry.

In particular, a cold cucible sor facility for the melting of adioactive bulls trom reprocessing is presently uncer consinsction in tie ApM at harcoule. It should come on stream in 1992 and process hulls issued tion the ierocessing of the fivel torm the Pherix

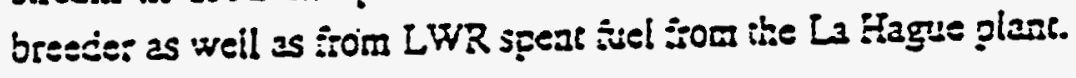

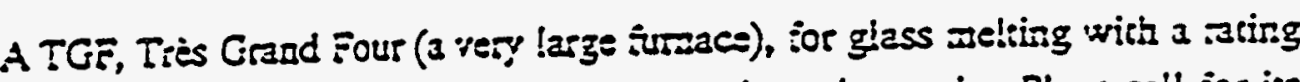
of $260 \mathrm{~kg}$ ger bour and a bold up :eacining $500 \mathrm{~kg}$ is preseatly under soudy. Plans call for its

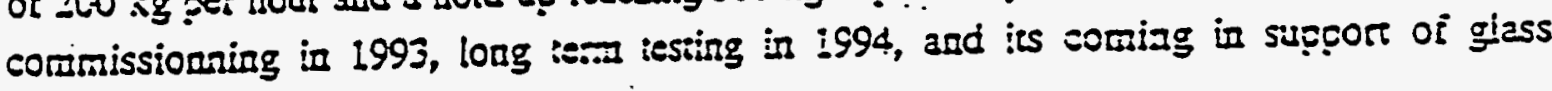
industives in 1995.

si?

$\ldots \infty 000$ 
TECHNIQUE

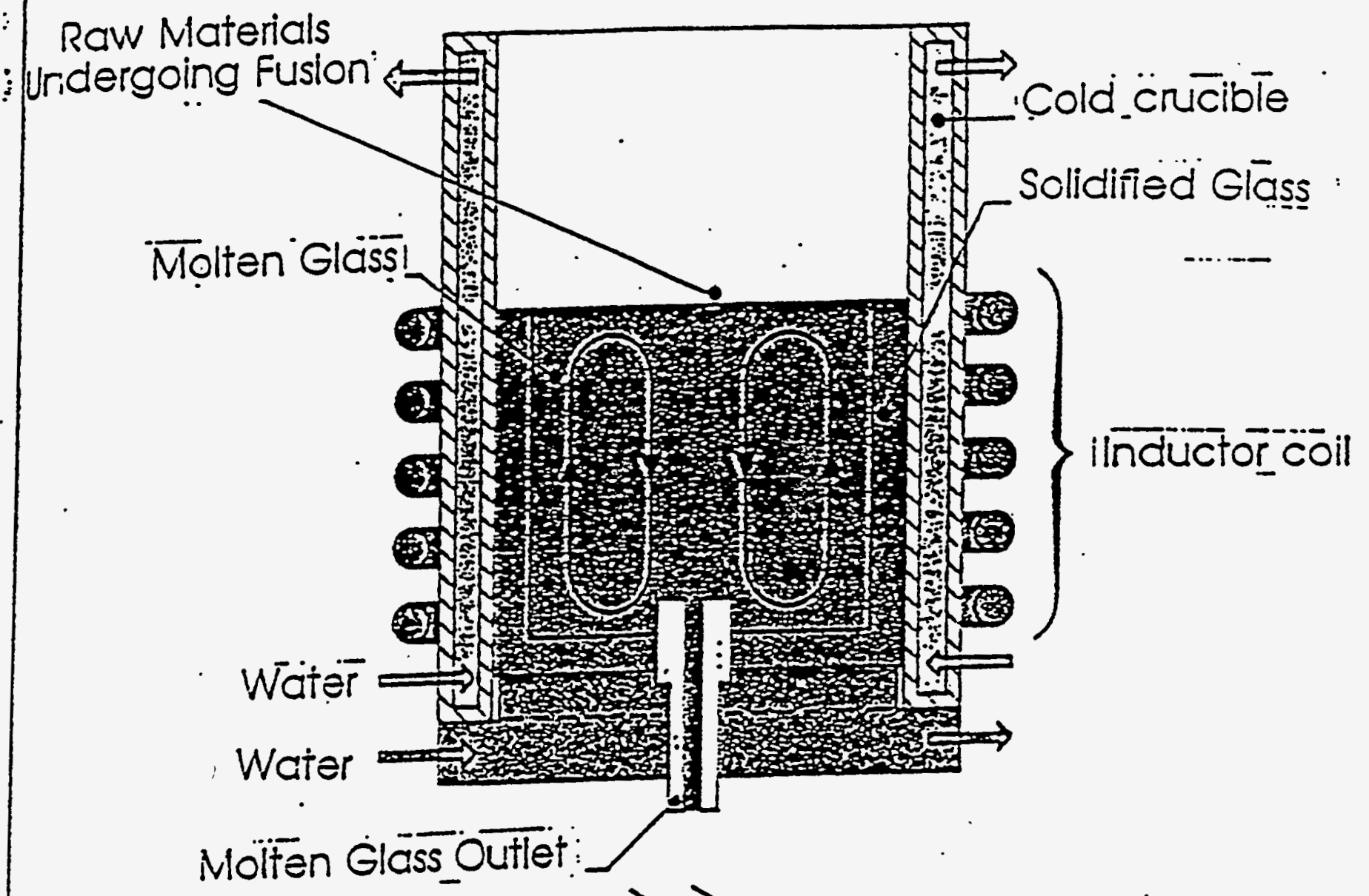

$?$

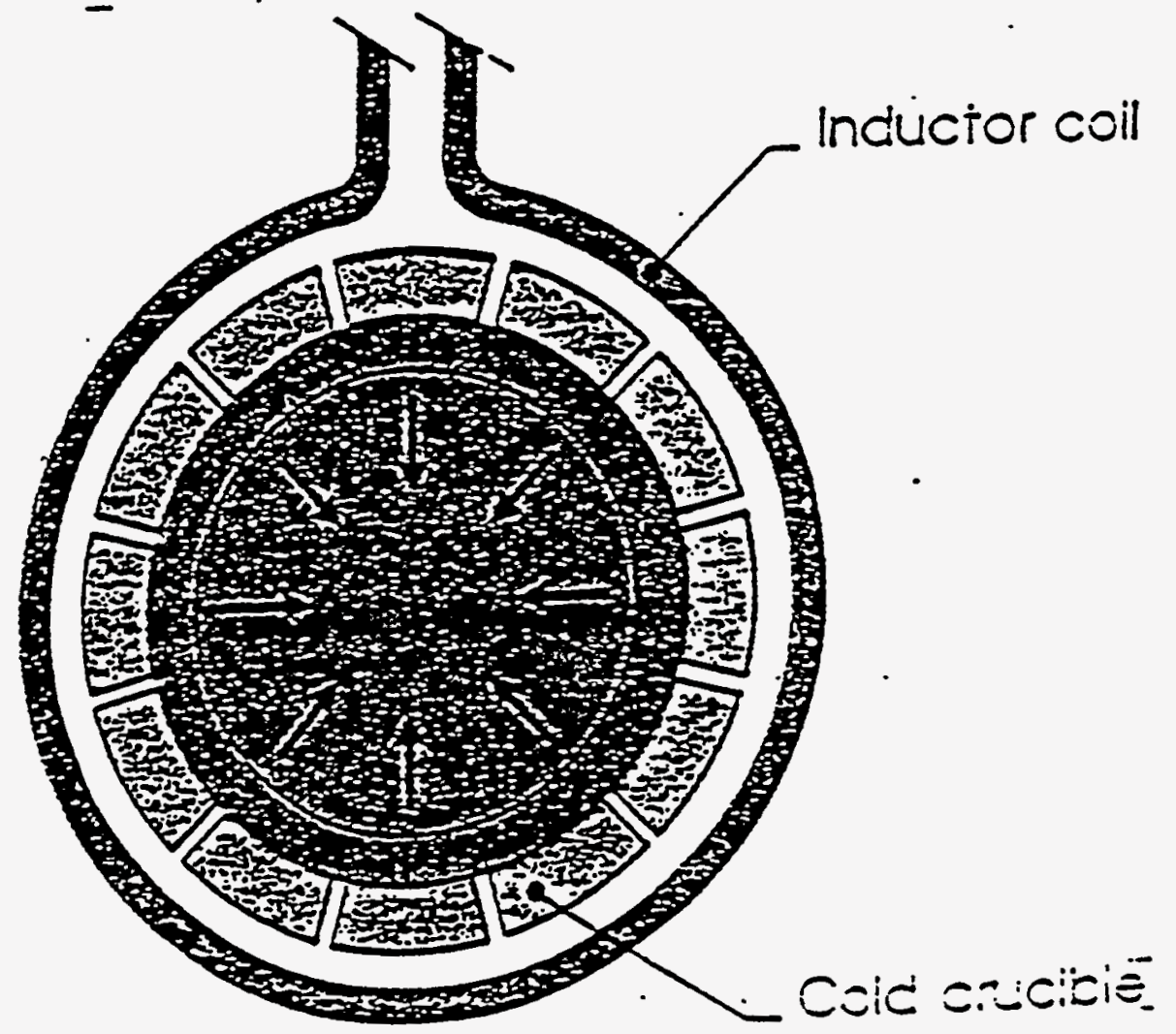

Fic. 1 


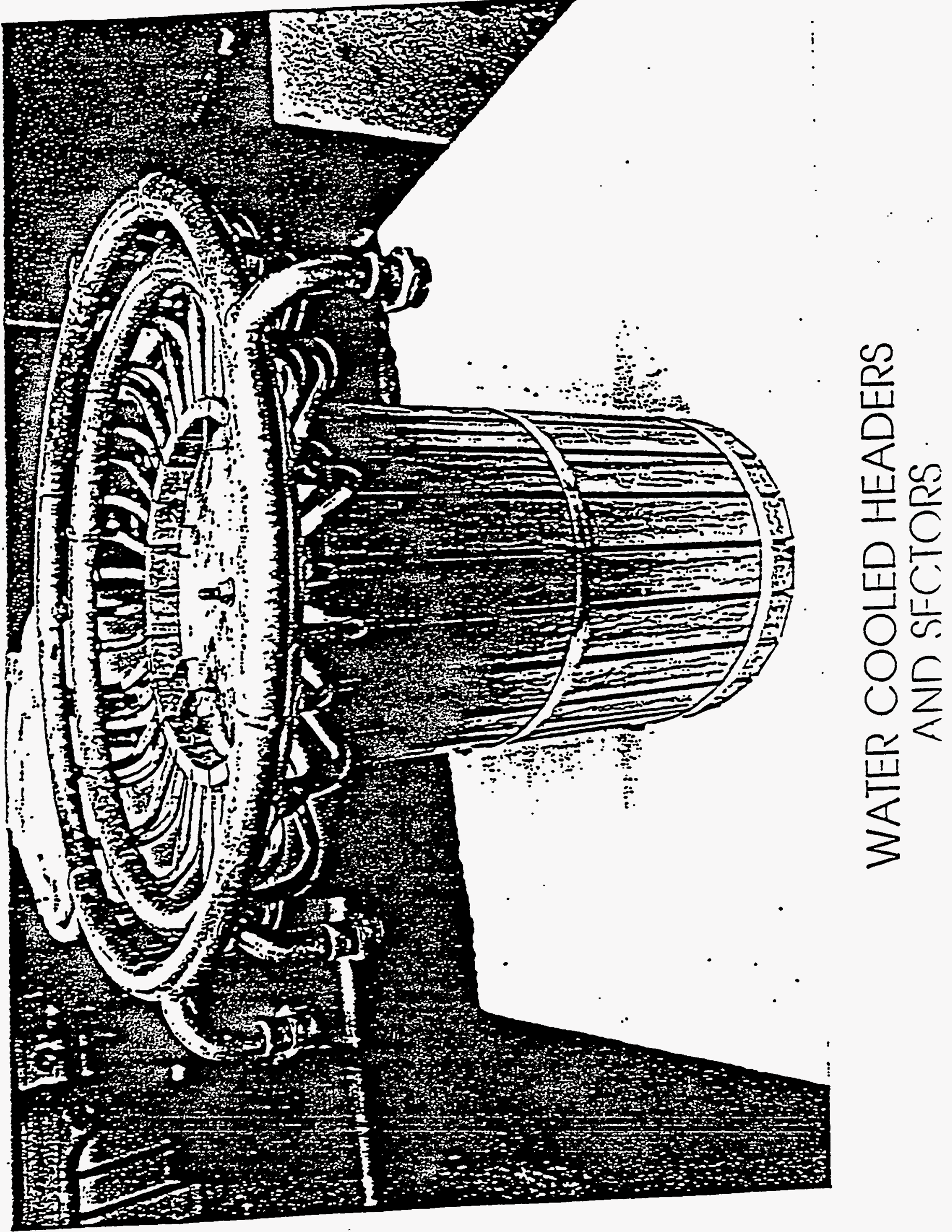

Fic. 2 


\section{HULL MELTING IN A COLD CRUCIBLE}

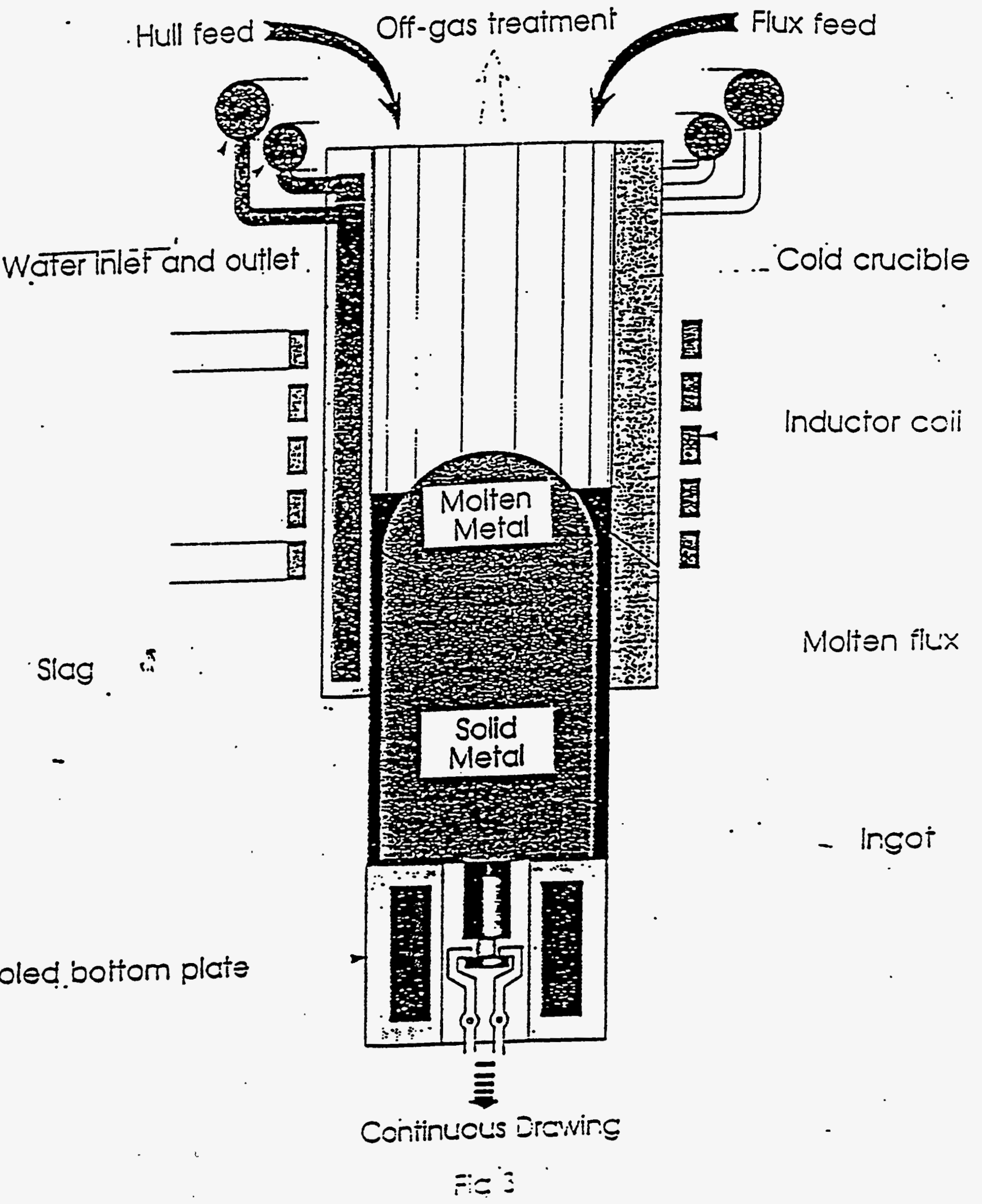




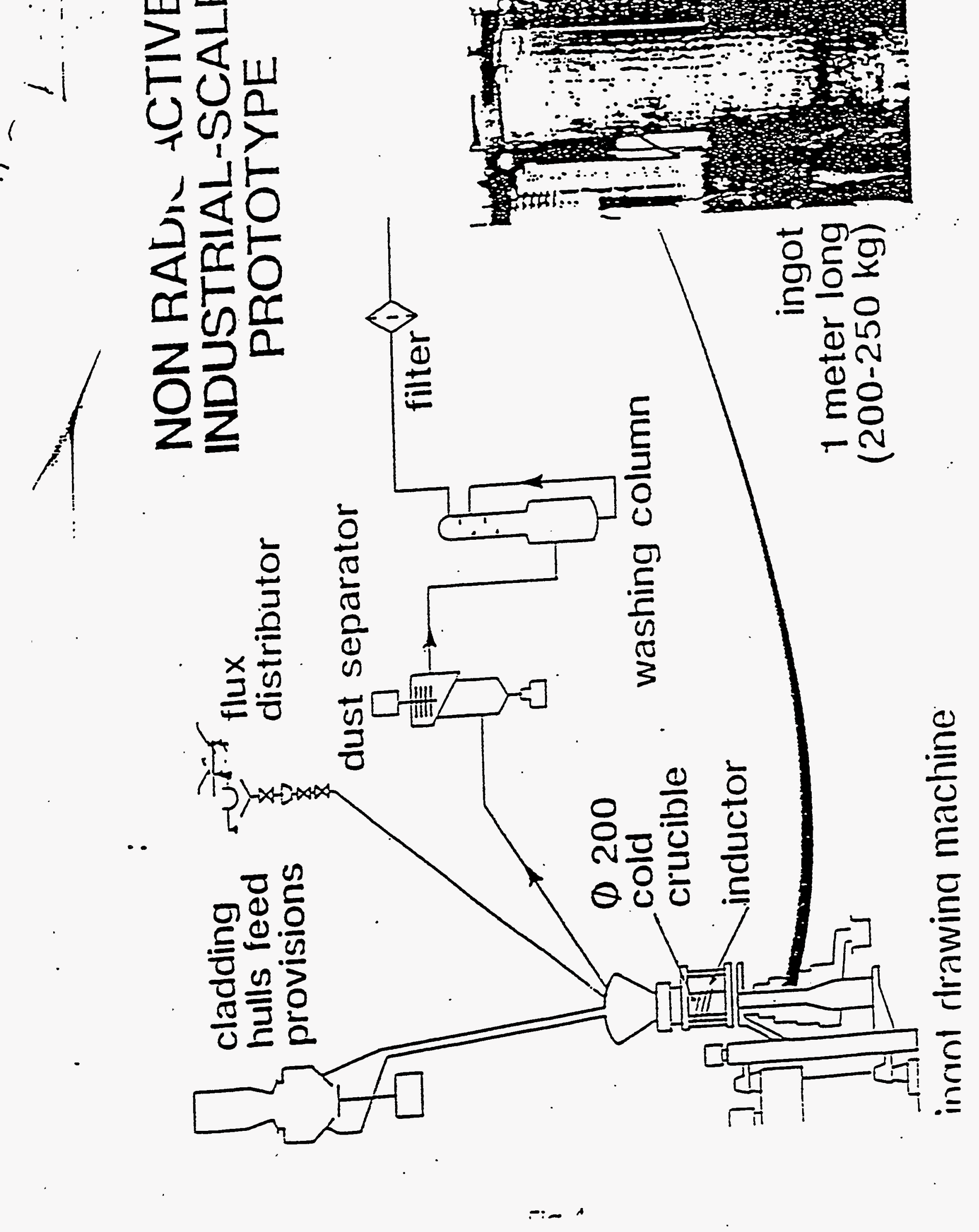




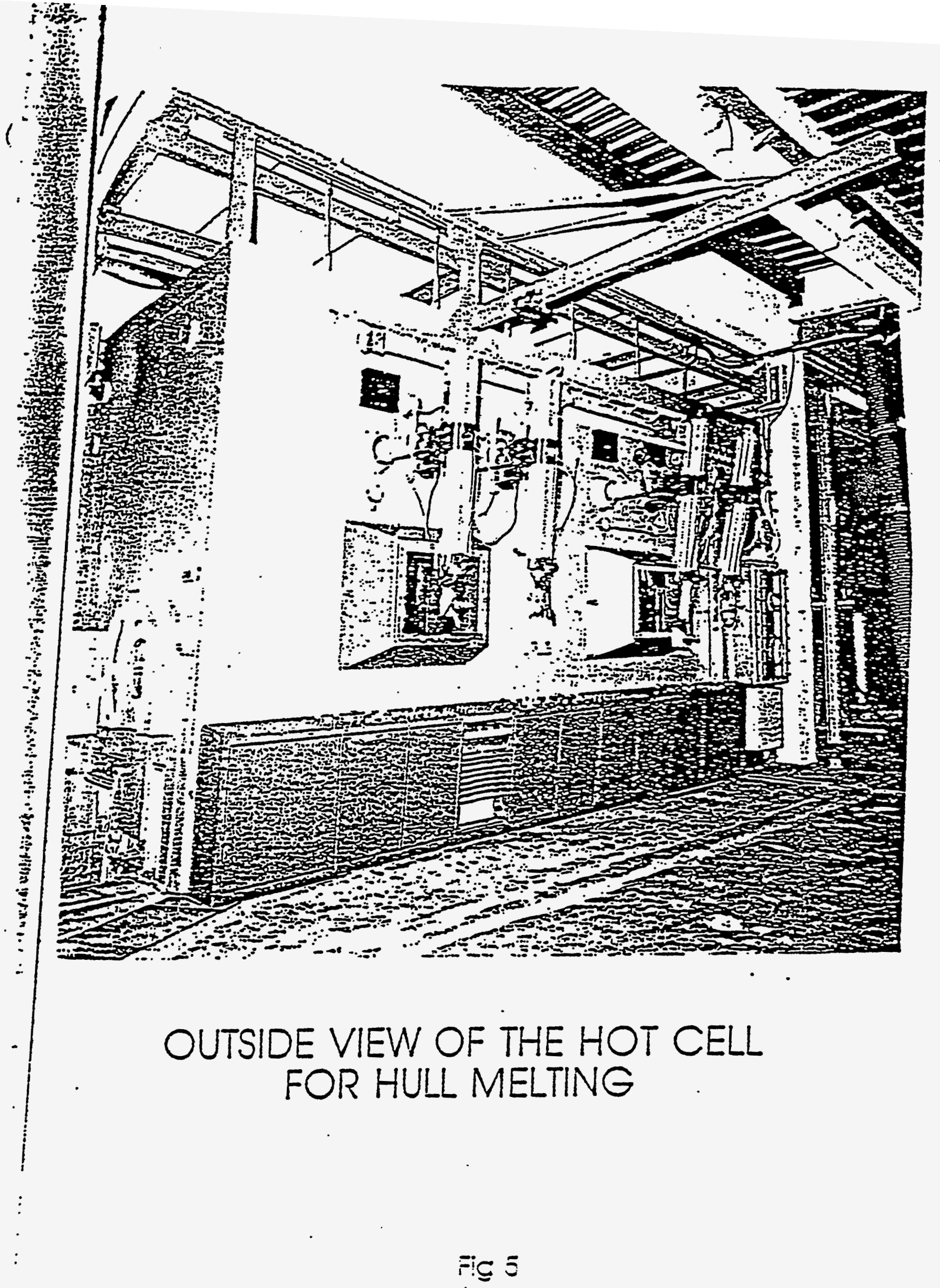




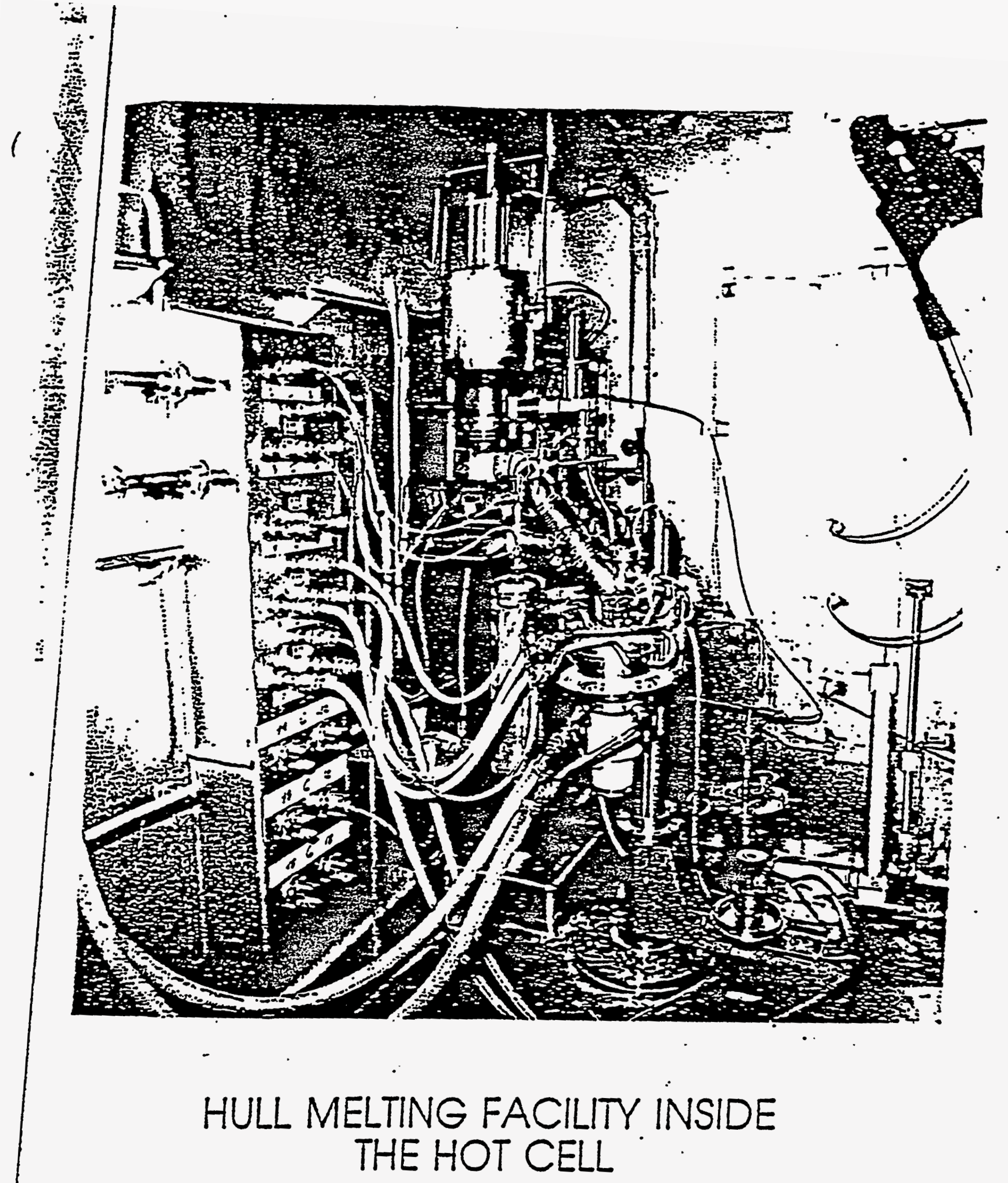




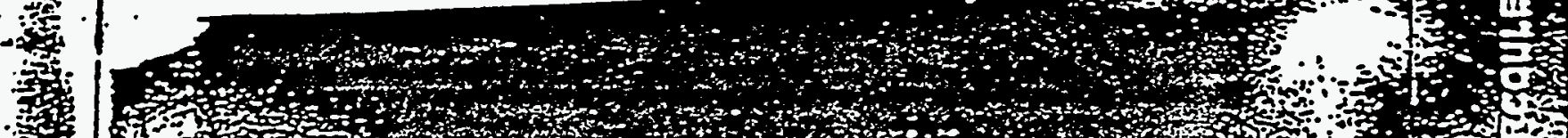

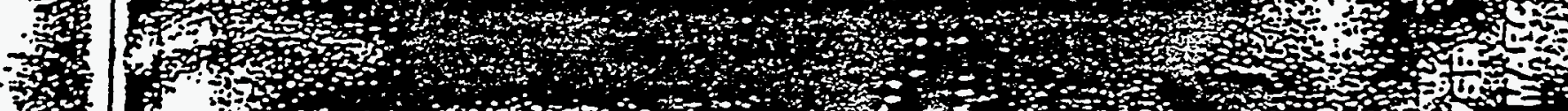

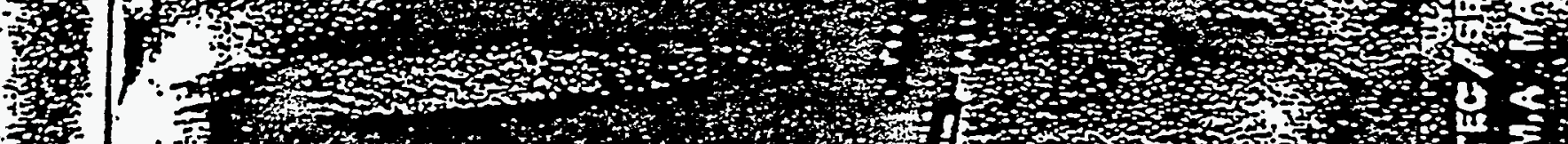

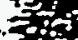

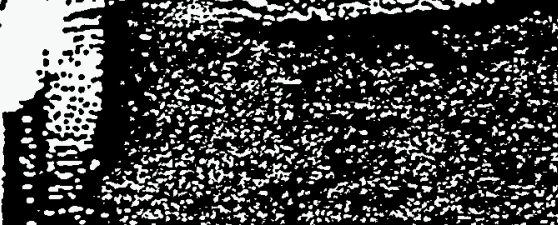

$+2$

4.

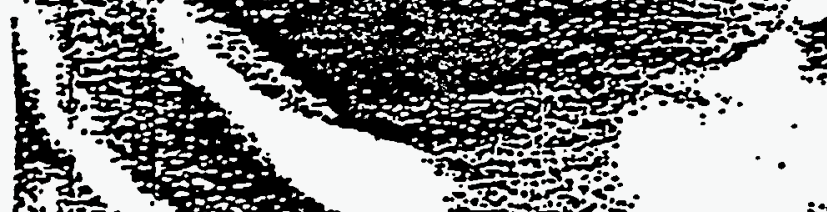

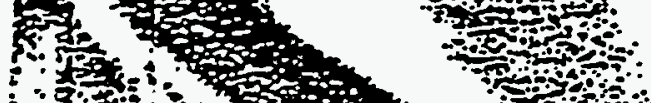

(n)

啭
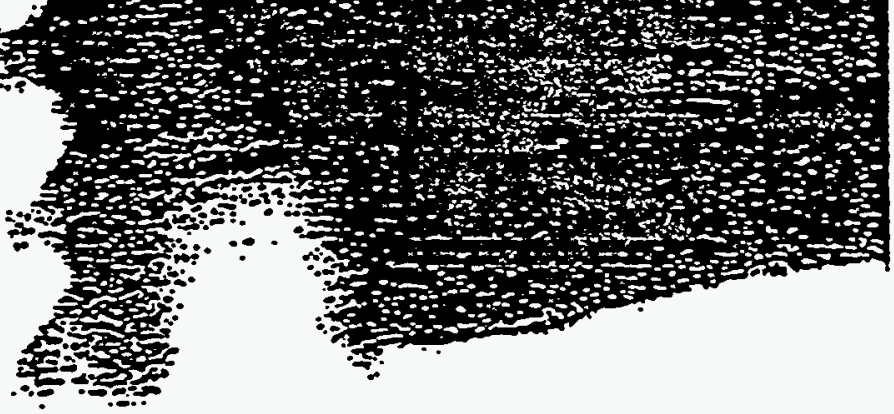


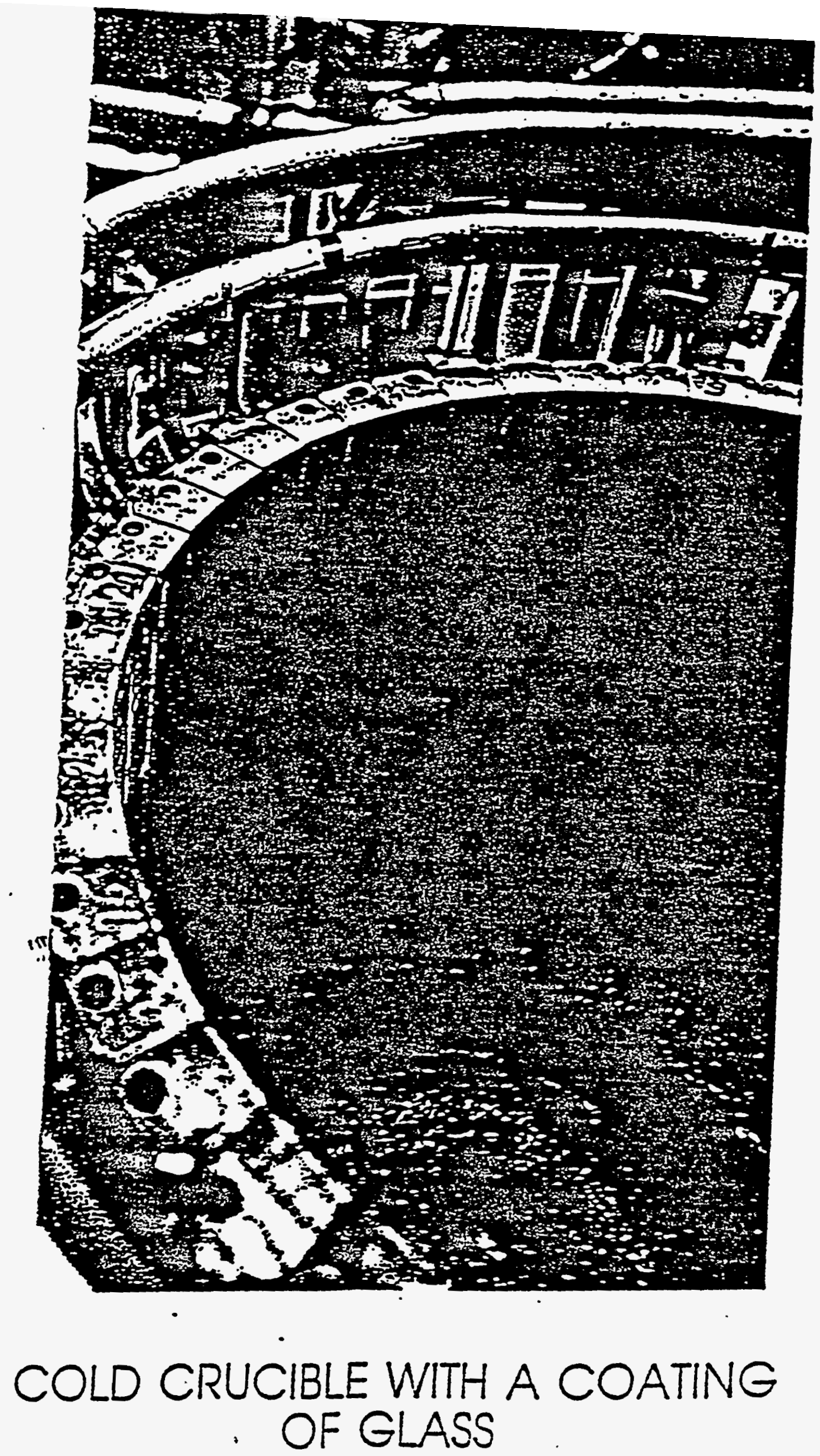

$F \subseteq 3$ 


\section{APPENDIX C}

\section{INFORMATION ON RUSSIAN COLD} CRUCIBLE MELTER DEVELOPMENT 
Info on Russion CCM

RADIOACTIVE WASTE MANAGEMENT IN THE USSR:

A REYIEN OF UNCLASSIFIED SOURCES

Yolume II

D. J. Bradley

March 1991

Prepared for

the U.S. Department of Energy

under Contract DE-ACO6-7ERLO 1830

Pacific Northwest Laboratory

Richland, Washington 99352 


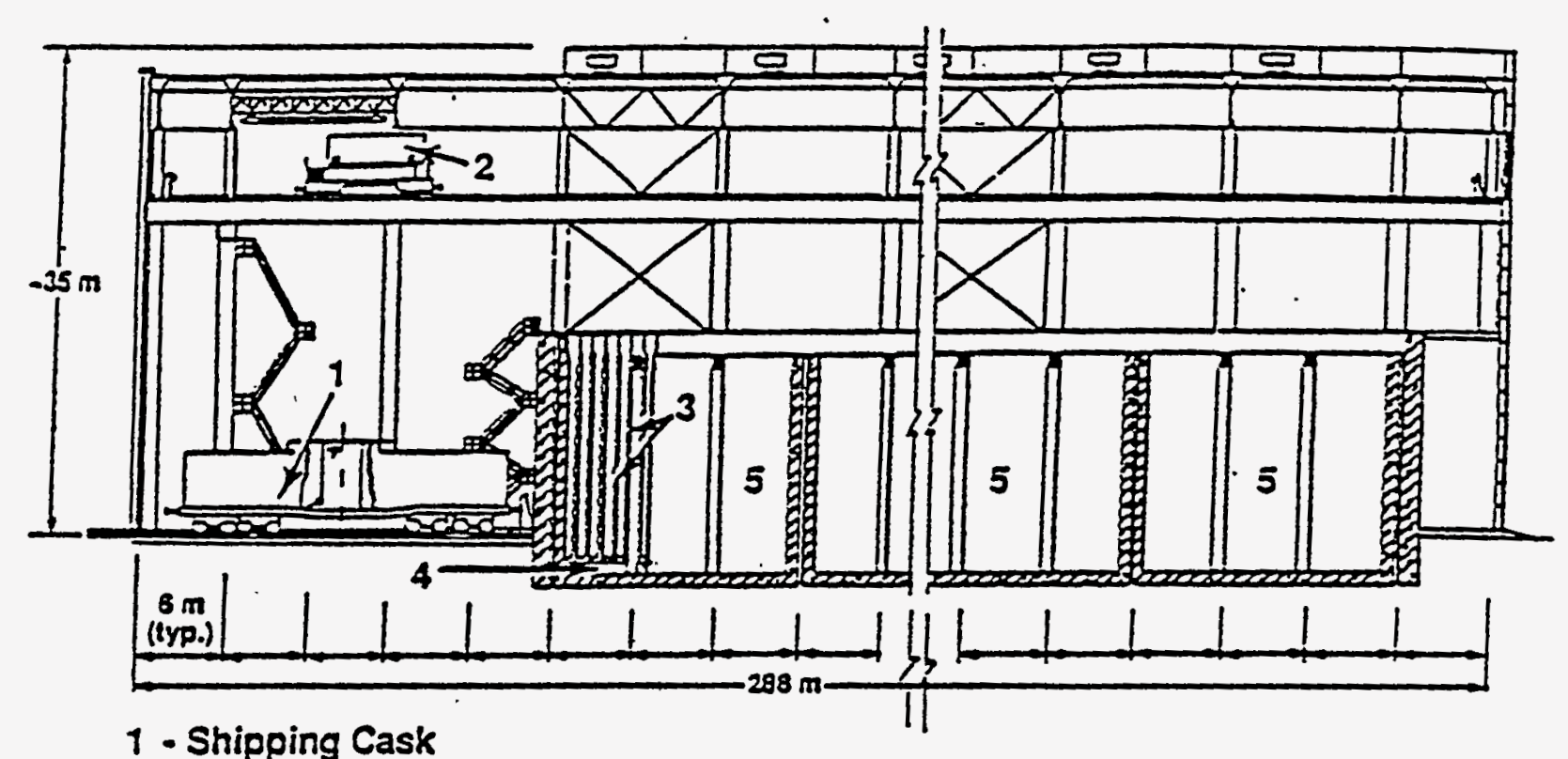

2. Crane

3 - Reinforeed Concrete Shaft for Cans

4 - Air Duet

5 - Storage 8ays

FIGURE 8.5. Natural-Circulation-Cooled Storage Facility for Vitrified Hastes (Nikipeiov at al. 1990a)

Further details on the two-stage vitrification process were given in a recent paper by B. V. Nikiforov. The process revolves around a method to drythe liquid wasta and then alt the waste in.a second stage using a highfrequency induction melter with a so-called "cold wall" or "coid crucible" design to help contain the welt and decrease corrosion of the neltar maizrials. The expected design capacity of the system is $100 \mathrm{~L} / \mathrm{h}$ of ieed solution ax $25-35 \mathrm{~kg} / \mathrm{h}$ solidified product. For the first stage, fluidized bed, soray and rotating horizontal calciners as well as a once-through evaporator have been studied. It appears that only the once througin "tube in tube" evaporator meets their engineering and capacity requirements. Experiments with the onca-through evaporator have showed satisfactory operation with up to $100 \mathrm{~L} / \mathrm{h}$ feed.rata of solutions with salt contents up to $350 \mathrm{~g} / \mathrm{L}$ (Nikiforov et al. 1990).

The perforanca of the inductive melting process has been experimentally demonstrated in the cold crucible at temperatures from $12000^{\circ} \mathrm{C}$ to $2300^{\circ} \mathrm{C}$. This 
process may be used to produce glassy-crystalline and "mineral-like" materials. such as pyroxene and pyrosilicates, titanates and titano-silicates, ferrogarnets and ferrosilicates, and Synrock-C.

All these materials have been prepared using the induction melting process at a temperature of $1250^{\circ} \mathrm{C}$ to $1550^{\circ} \mathrm{C}$, and then treated at $650^{\circ} \mathrm{C}$ for two hours to simulate annealing, and irradiated to $10^{10}$ rad to determine their radiation resistance. Chemical stability was determined by an "express" [rapid] method under "contact with distilled water fraction 0.15-0.25nm" at a temperature of $60^{\circ} \mathrm{C}$ during 1 hour (Nikiforoy et al. 1990). Tentative results showed that sphene, ferrogarnet, and a complex type of giassy-crystalline pyroxene have high chemical stability, jadeite, aegirine-augite and andradite were the most stable, and synroc "type" materials were "intermediate" in durability.

The Soviets have developed "cold crucibles," made of stainless stael and "sealed" by refractory materials, with a tank area of $0.05-0.12 \mathrm{~m}^{2}$. At a mean temperature of $1500^{\circ} \mathrm{C}$, operating in the "continuous mode," they have demonstrated production of sillicate materials at $12.18 \mathrm{~kg} / \mathrm{h}$. Details of their design ara given in Table 3.1. Figures 8.5 and 8.7 show a general hot cell arrangement for the two-stage vitrification-procass and concept of the induction-heated cold crucible melter, respectively (Nikiforoy et a1. 1990). It should be qoted that two-stage vitrification processes have been under development since the 1970s in the Soviet Union. A diagram of the KS-KT-100 twostage vitrification process is shown in Figure 3.3 (Nixiforoy et al. 1985).

- The yrinciple of transmutation, as stated by the Soviet scientists, is to separate actinides, fission products, and/or isotopes of long half-itife and subject these isafopes to high fluxes of thermal neutrons, protons, or lasers. It was indicatad thatheavy water reactors will be used to produce neutrons which will bombard a nixtwe of Lithium and wasto (with an approxinate composition of: $237 \mathrm{~Np}-35 \%, 243 \mathrm{Ap}-27 \%$ and $\mathrm{CD}-44 \%)$. Approximataly 500 to $1000 \mathrm{~kg}$ per year of actinides will be "burnt" (National Academy of Sciences 1990). Nork along these lines has recintly been reportad by the Ukrainian Academy of Sciences Institute of Physics and Tecinnology in Kharkov. Scientists have installed "several new $100 \mathrm{Mel}$ accshutors" at an unspecified 
TABLE 8.1. Specifications of the Two-Stage Vitrification Process Using a Spray Calciner and Induction Melter with a Cold Crucible

Soray Orver-CaTciner (RS-100)

1. Diameter, $m$

2. Height, $\mathbf{m}$

3. Material, Chloniot (Stainiess Stael)

4. Furnace Power, KW 240

5. Electrical Consumption, X/h/L 0.9

6. Working Temperature, ${ }^{\circ} \mathrm{C}$ 750

7. Production Based on Feed Solution, L/h

\section{Induction Melter with Cold Crucioie (iPCint)}

1. Inductor Power, $x$ H

2. Operating Frequency, Megaitz

3. Crucible Material I2ChizNiot (Stainless Steel)

4. Dimensions of "Cold" Crucibie, am $500 \times 300 \times 500$

5. Operating Temperatures, ${ }^{\circ} \mathrm{C}$ $900-2300$

б. Production Based on End Product (Glass or Mineral-Like), $\mathrm{kg} / \mathrm{h}$

nuclear station to bombard isotope targets with electrons. Full-scale "experiments" are scheduled to begin latar in 1990 (Nuclear Nasea News Hay 10 , 1990).

The Khlopin Radium Institute is conducting research on partitioning of HLW using the organic compound cobalt dicarbolyl anion in $\mathrm{HNO}_{3}$ acid solutions. This reagent is especially effective for large ions, and the process separates $S r, C S$, REE and TRU with efficiencies up to 99\%. CS and Sr were reported to 


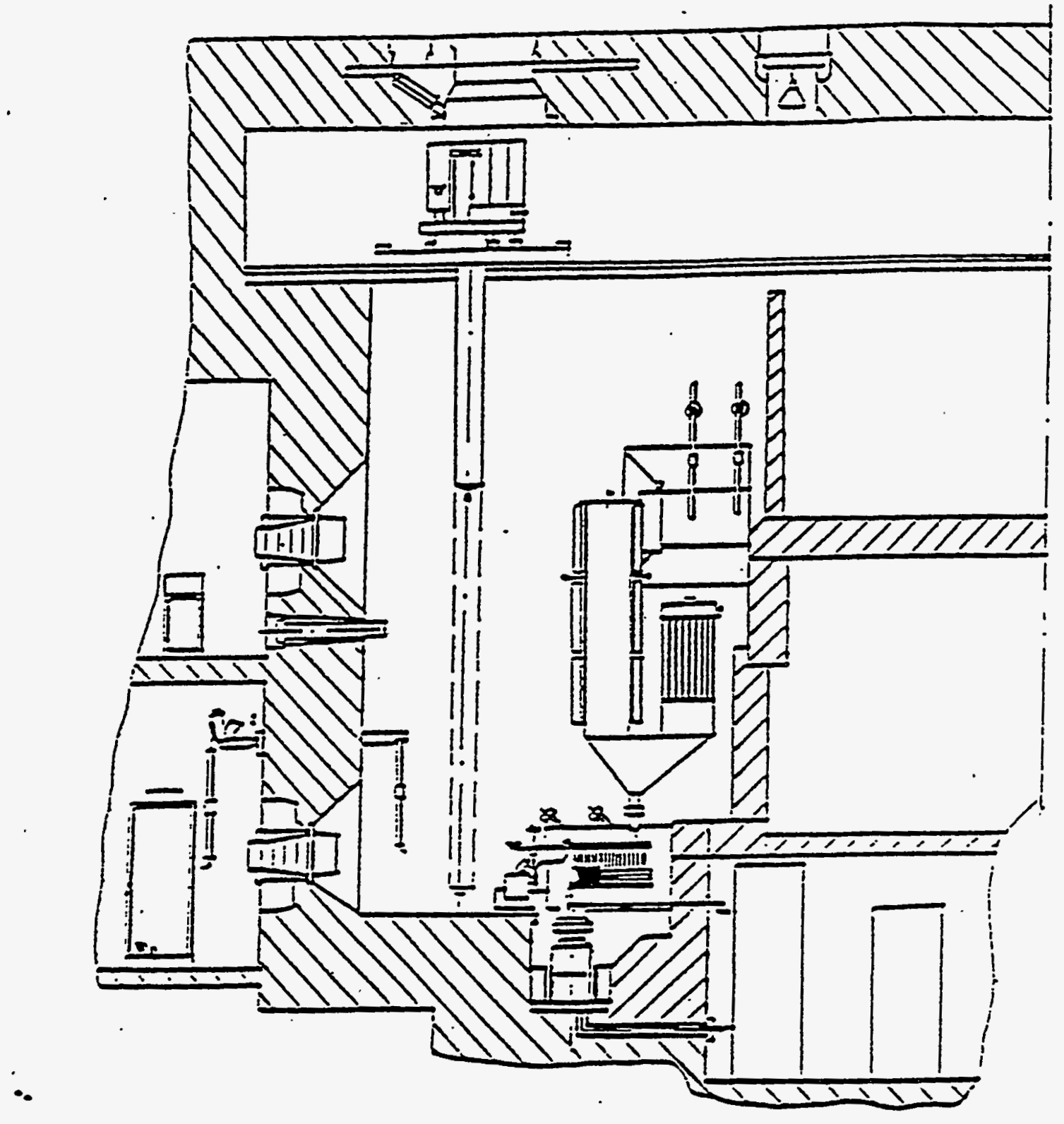

FigURE 8.5. General Hot Call Arrangement for the Two-Stage Vitrification Process (Nikiforov et al. 1990) 


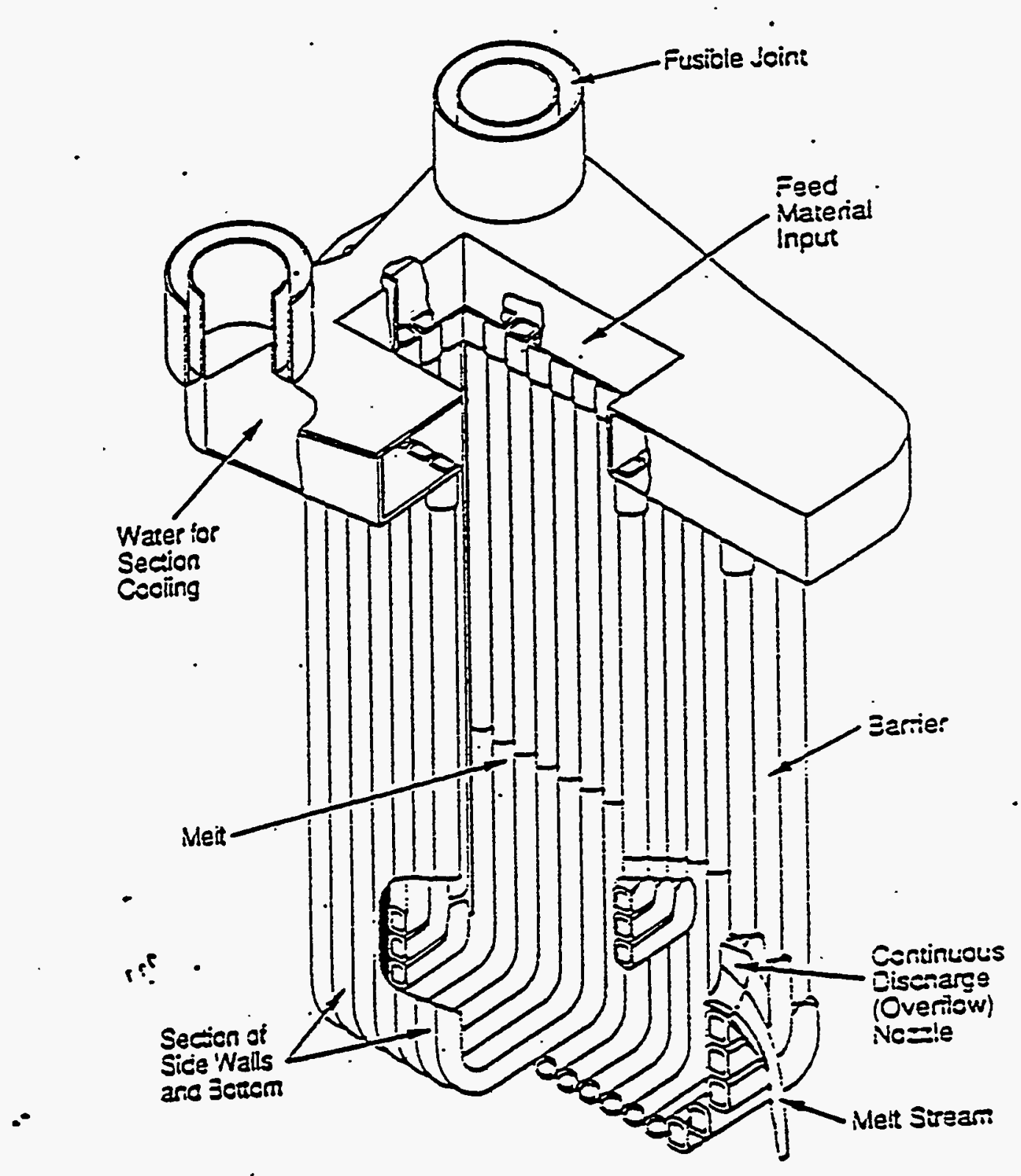

FIGURE 3.7. Orawing of the Induction-Heated cold Crucible Melter Concapt (Nikiforov et al. 1990)

$8.1 !$ 
Multinational Environmental Outlook. May 1, 1990. "Chernobyl Plans Four Still More," p. 1.

National Academy of Sciences. 1990. Trip Report of the Visit of the National Academy of Sciences Delegation on Radioactive Haste Management to the USSR, February 12-23, 1990, Washington, 0.C.

New Scientist. July 22, 1989. "Military Reactors Go on Show to American Visitors."

Nikiforoy, A. S., V. V. Kulichenko, and H. I. Zhikharev. 1985. "Oisposal of Liquid Radioactive Wastes," Translated from the Russian Obezvrezhivanie zhidkikh radioaktivnykh otkhodov, Hoscow: Energoatomizdat, 1985.

Nikiforov, A. S., V. E. Vlasov, Y. Y. Kushnikov, N. X. Krilova, T. S. Smelova, and R. N. Salamatina. 1990. "Development of a Two-Stage Process for Consolidation of Highly-Active Mastes." All-Union Institute of Inorganic Materials of Academician - A. A. Bochvar. Ministry of Atonic Power and Industry. Paper given during the U.S. Department of Energy visit to the Soviet Union, June 15-29, 1990 .

Nikiforoy, A. S. September 1990a. "Policy and Principles of Radioactive Waste Management in the USSR," A. A. Bochvar All-Union Scientific Research Institute of Inorganic Materials, Moscow, USSR. Presented at a colloquium on Septamber 4, 1990, at Los Alamos National Laboratory.

Nikitorov, A. S. September 1990b. "Status and Problems of Nuclaar Fisel Cycle," Ministry of Atomic Power and Industry, Moscow, USSR. Presented at a colloquium on September 4, 1990, at Los Alamos National Laboratory.

Wikiforov, A. S., 3. S. Zakharkin, and A. M. Rosen. September 1990C. "Extractarits for Actinides," All-Union Scientific Research institute of Inorganic Matisrials, Moscow, USSR. Prepared for the ENC 90 Conierence, Septamber 23-28, 1990, in Lyon, france.

Nikiforov, A. S., A. S. Polyakov, Y. Y. Kushnikov, V. A. Bel'tyukov, $V:$ I. VIasov, and G. 8. Borisoy. Septemier 19g0d. "USSR Experience in HighLavel Waste Management," All-Union Scientific Research Institute of Inorganic Materials, Moscow, USSR. Proparad for the ENC 90 Contaranca, Septamber 23-23, 1990, in Lyon, France.

Nikipelov, B. Y., G. N. Romanov, L. A. 3uldakov, N. S. Babev, Yu. B. Kholina, and E. I. Mikerin. 1990. A Radiation Iccident in the Southern Urals in 1957, Original article submitted July 14, 1989, Plenum ?ublisining Co.

Nikipelov, B. V., Ye. I. Mikerin, A. S. Nikiforov, A. S. Poliakov, V. G. Shatsillo, V. A. Kurnosov, M. V. Strakhov, A. P. Suslov, V. I. Labedev, and Yu. $V$. Xuznetsov. 1990a. "Ya in Trands and the Results of Works Made in the USSR on Solidification of High- and Medium-Level Liquid Wastes." State Conmittee of the USSR for Utilization of Atomic Energy. Presented on $3 / 25 / 90$ during a visit to the U.S. 


\section{APPENDIX D}

\section{PRESENTATION FROM TRIP TO FRANCE}

ife 
Ce circuit fermé fait écran
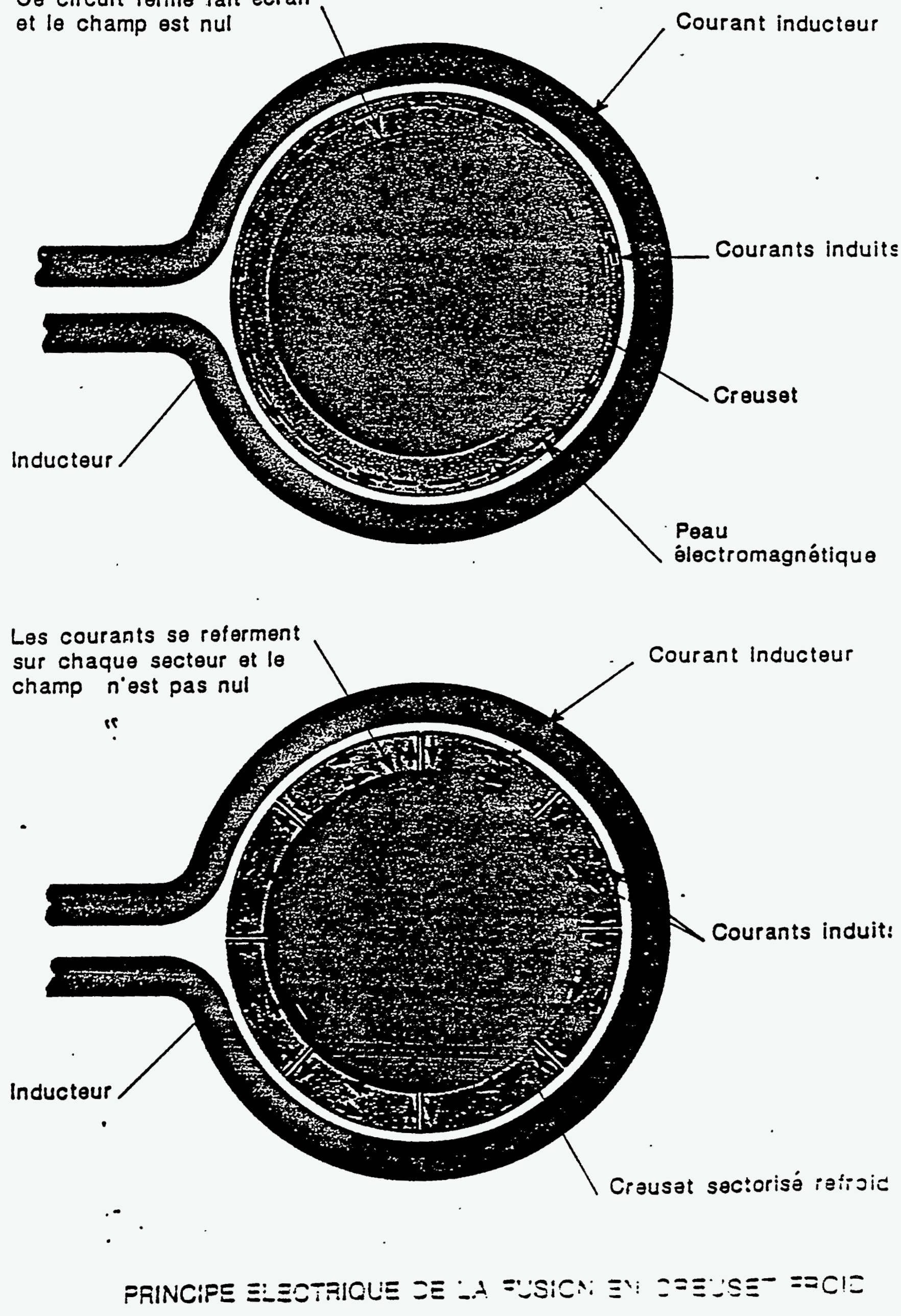


\section{PRINCIPE DE LA FUSION EN CREUSET FROID}

Couche de produit de base en cours de fusion

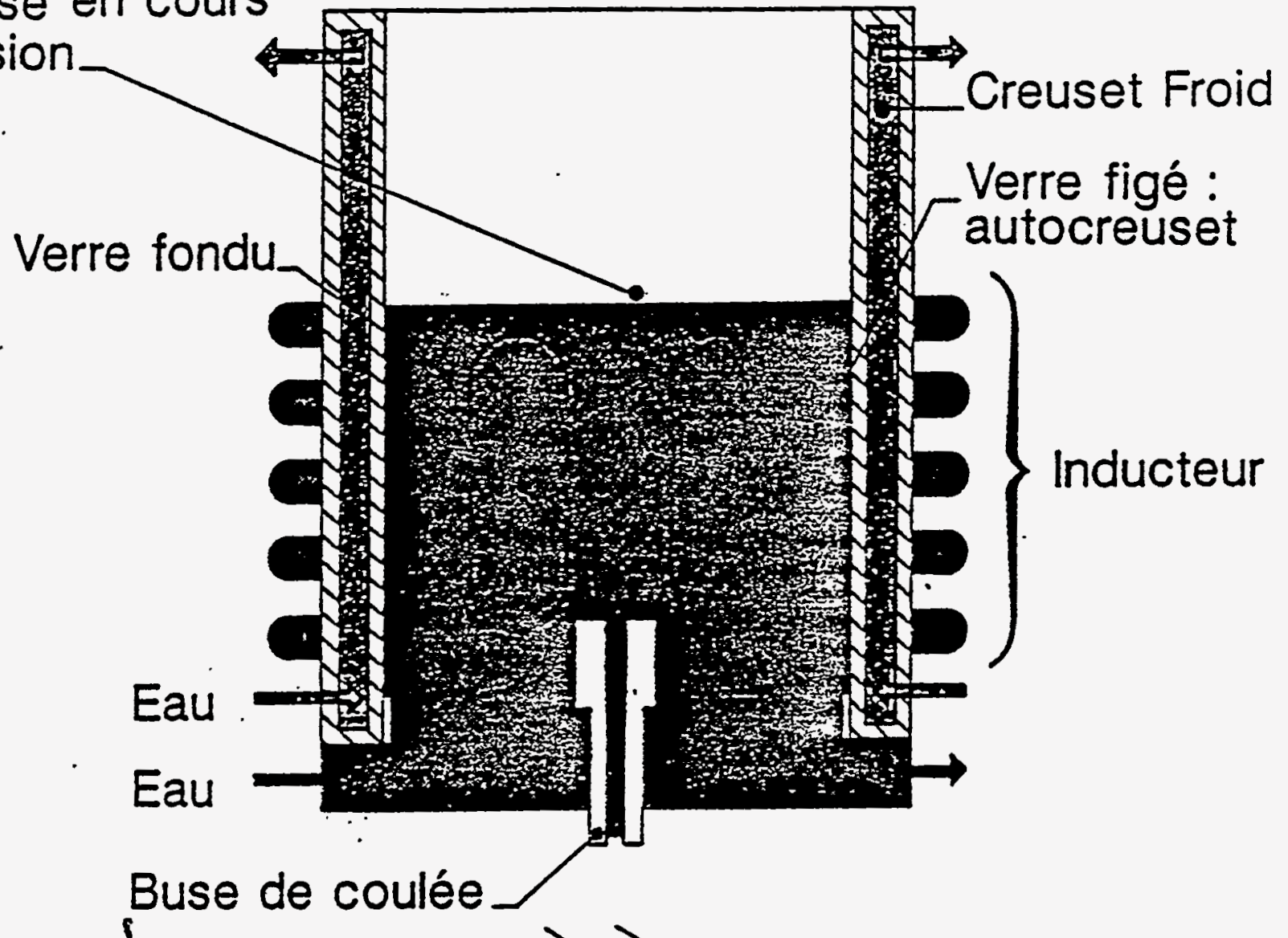




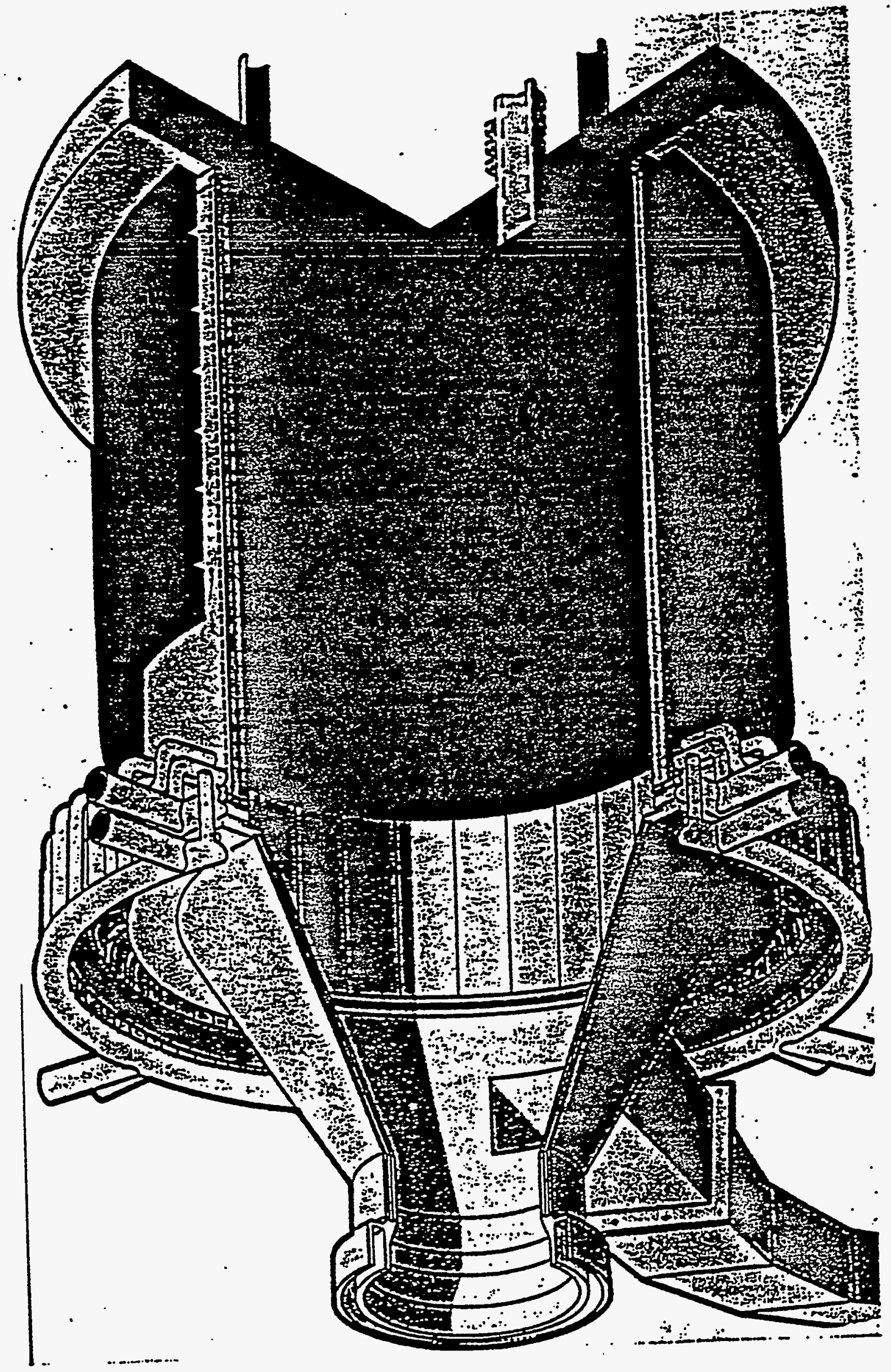




\section{COLD CRUCIBLE TECHNIQUE}
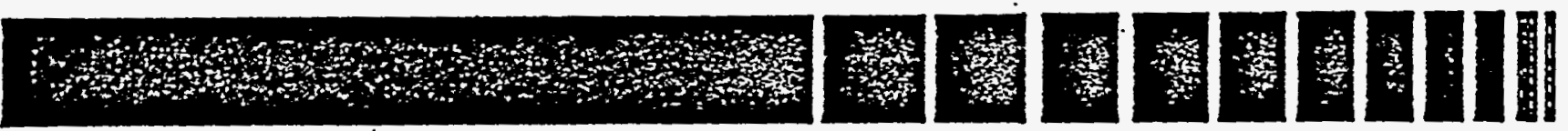

\section{Using electric induction}

- High frequency magnetic electric field coming from a coil

» electric current directly into the product to be heated

\. power coming from the Joule effect

$$
P=R^{2} \text {. }
$$

- power directly in the product

- high temperatures possible

- high specific power possible 


\section{GLASS MELTING IN COLD CRUCIBLE
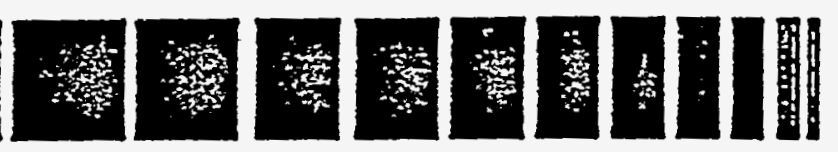

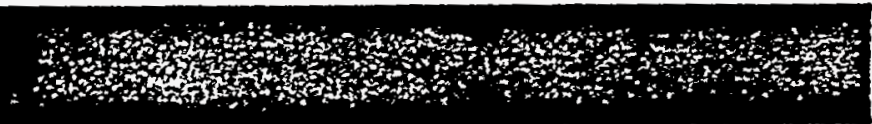

No contact between crucible and melting glass

No wear of the crucible. Life time :10, 20, 30 years?

No contamination of the cold crucible (or very low)

No limit of temperature

$$
\begin{array}{cc}
\mathrm{ZrO2} & 2750^{\circ} \mathrm{C} \\
\mathrm{UO} 2 & 2800^{\circ} \mathrm{C}
\end{array}
$$




\section{GLASS MELTING IN COLD CRUCIBLE}
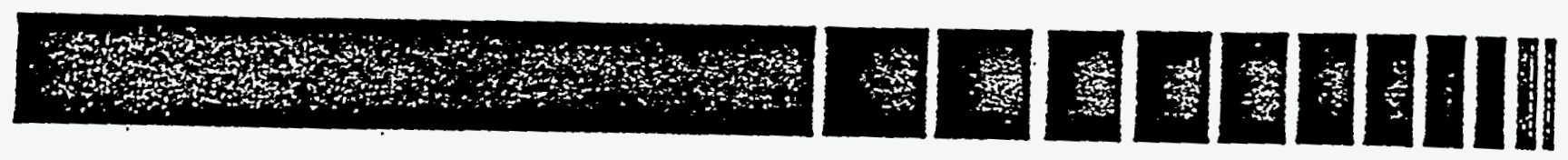

When cold, glass is an electric isolating material

-.-> no possibility to introduce power in the glass !

It's necessary to preheat a little "part of the glass using an other mean

---> for nuclear purposes, microwaves are proposed

It's necessary to keep, continiously a part of melted glass, in the bottom of the crucible 


\section{COLD CRUCIBLE EQUIPMENT}

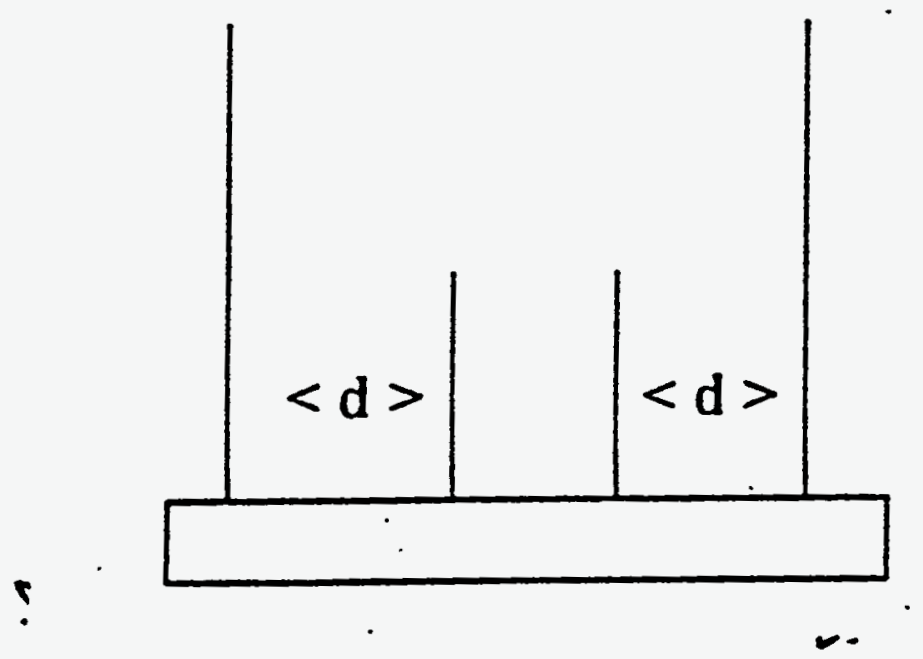

- The depth of the electric current penetration "d" is reciprocally proportional to the current frequency

$$
\mathbf{D}=\frac{\mathbf{K}}{\mathbf{F}}
$$

$50 \mathrm{~cm}$

$1 \mathrm{~m}$
$200000 \mathrm{~Hz}$ $50000 \mathrm{~Hz}$ 


\section{COLD CRUCIBLE TECHNIQUE}
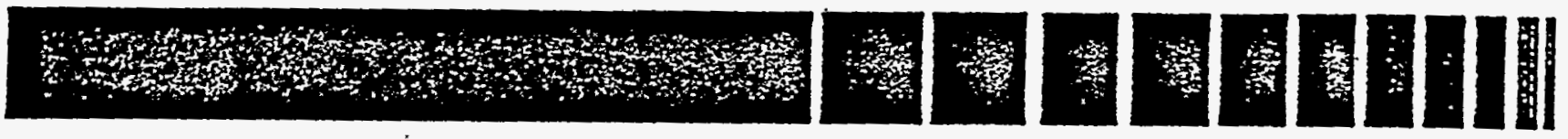

\section{Q Power balance}

- electric losses in the coil $\quad 10 \%$

- electric losses in the cold crucible $20 \%$

- power into the glass

$70 \%$

to melt 30 to $40 \%$

s thermic losses 60 to $70 \%$

---> high electric power consumption but...glass is a thermic isolating material

Conventional melting (refractory furnace)

$1 \mathrm{kWh} / \mathrm{kg}$ of glass
Melting in cold crucible

.2 to $2.5 \mathrm{kWh} / \mathrm{kg}$ 


\section{COLD CRUCIBLE EQUIPMENT}
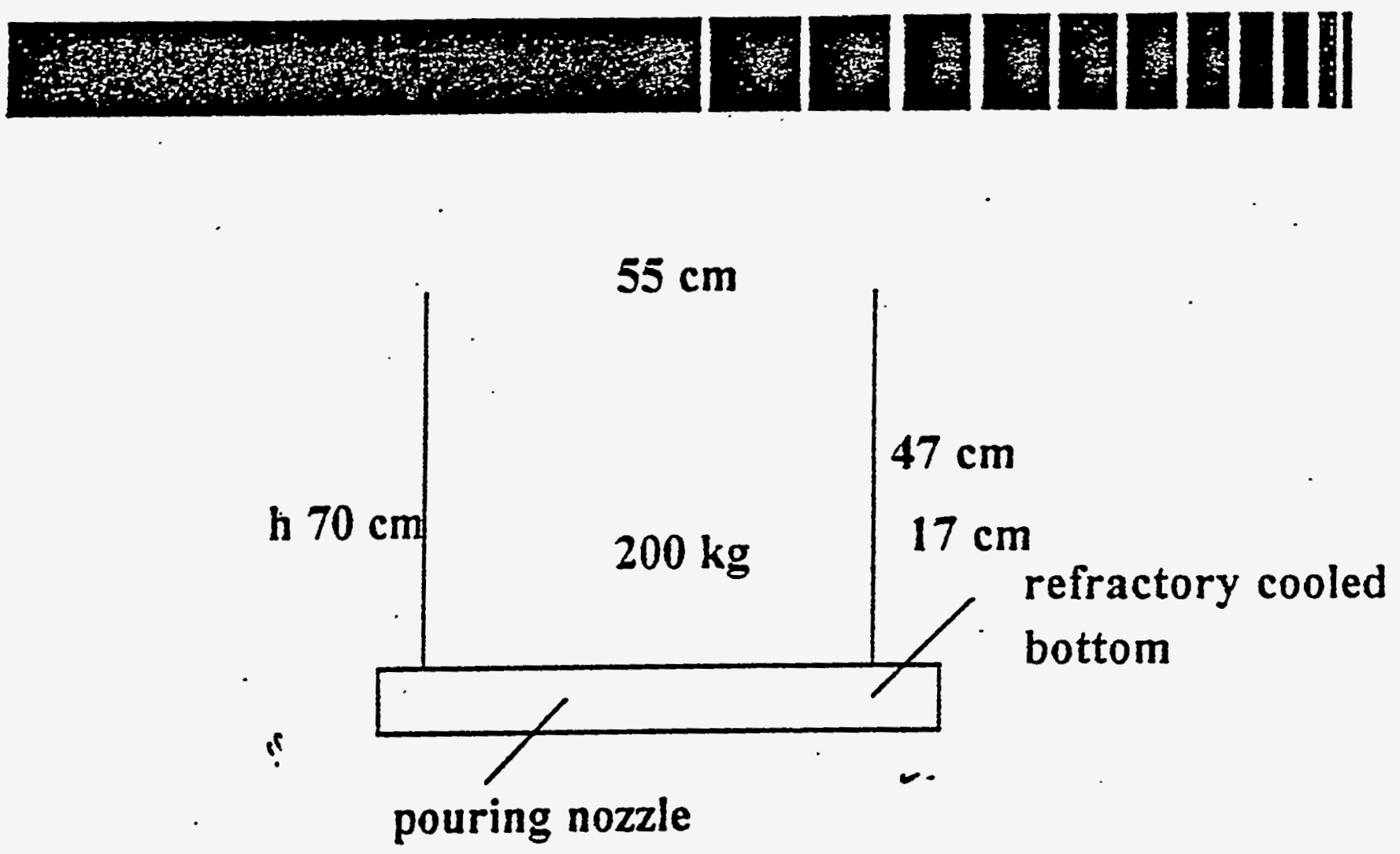

Tests have been made with this equipment connected to AVM calciner

$30 \mathrm{~kg} \cdot \mathrm{h}^{-1}$ is a possible capacity with $\mathrm{R} 7$ glass type 


\section{POSSIBLE CAPACITY OF A COLD CRUCIBLE MELTER}
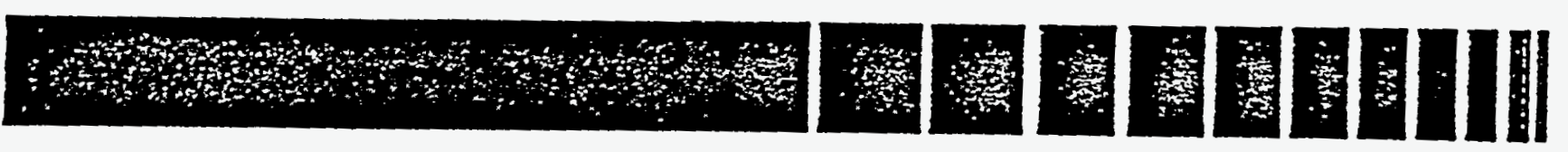

1. We have today demonstrated

$\phi 55 \mathrm{~cm}$

R7 type glass

$1200^{\circ} \mathrm{C}$

--->> $30 \mathrm{~kg} \cdot \mathrm{h}^{-1}$

It's probably not the upper limit

Flowrate is proportional :

to surface $\phi^{2}$

to temperature $\mathrm{T}^{4}$

and increases with stirring means

Example : $\phi 80 \mathrm{~cm} \rightarrow 63.5 \mathrm{~kg} \cdot \mathrm{h}^{-1}$

$\phi 90 \mathrm{~cm} \rightarrow 80 \mathrm{~kg} \cdot \mathrm{h}^{-1}$

(same temperature of $1200^{\circ} \mathrm{C}$ )

f $55 \mathrm{~cm} \rightarrow 55.6 \mathrm{~kg} \cdot \mathrm{h}^{-1}$

$\mathrm{f} 80 \mathrm{~cm} \rightarrow 80 \mathrm{~kg} \cdot \mathrm{h}^{-1}$

(at $1400^{\circ} \mathrm{C}$ ) 


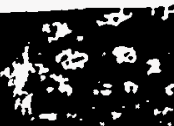

$\therefore$ (6)

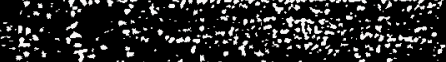

is

$\therefore$ (a)

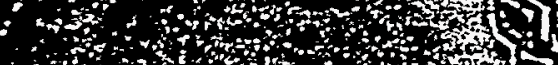

(a)

fin

(n)

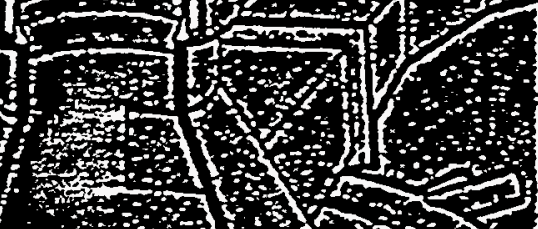

Fon

(n)

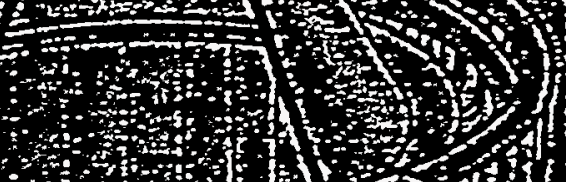

a

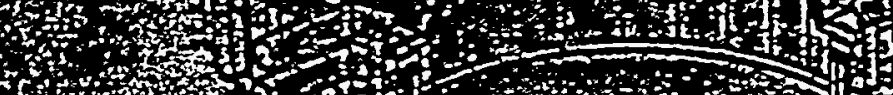

t

3. 3 , w

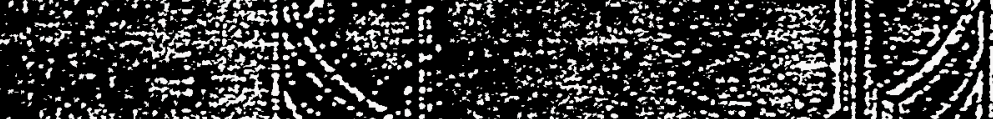

(1)

F,

(3)
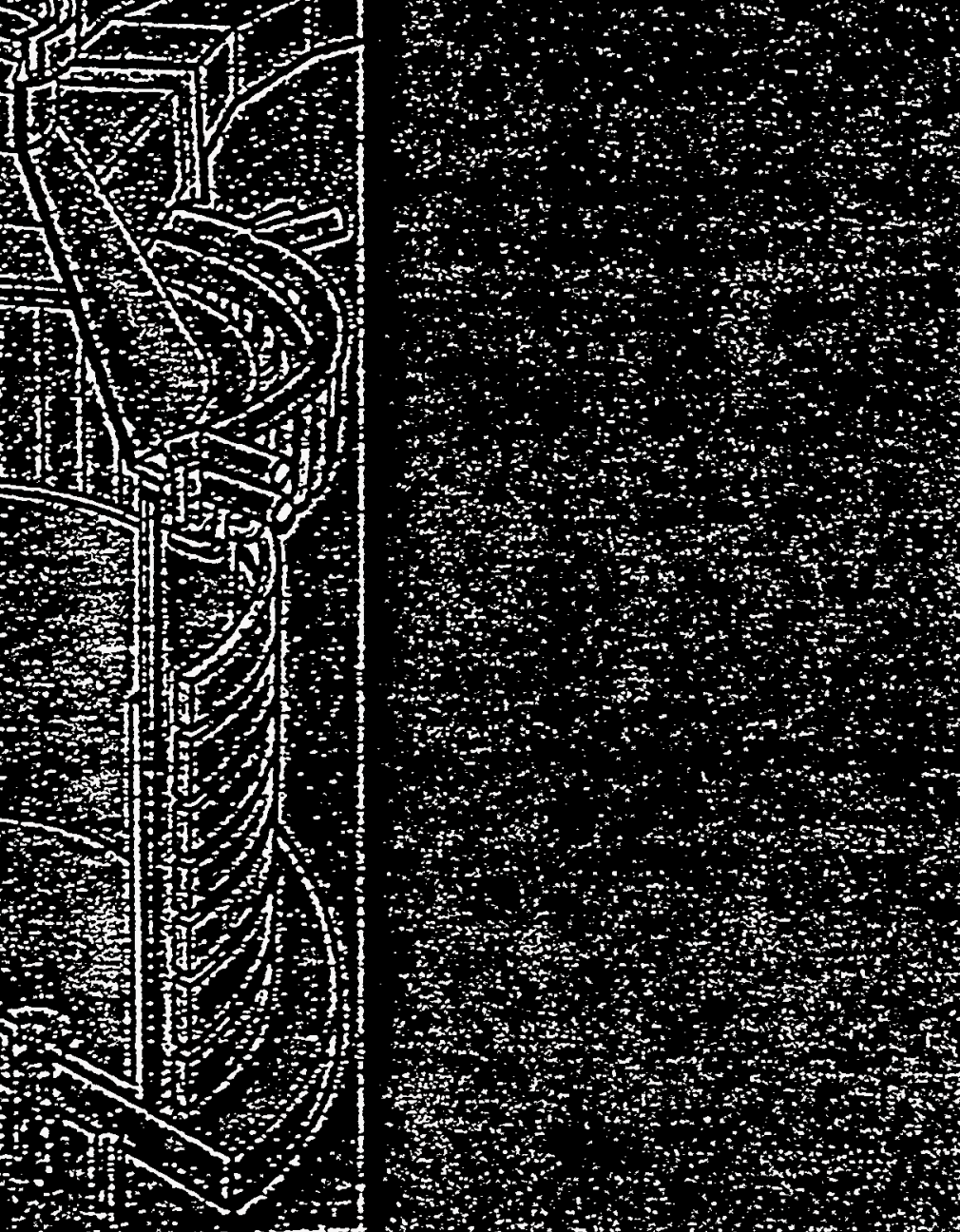

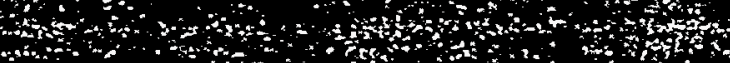

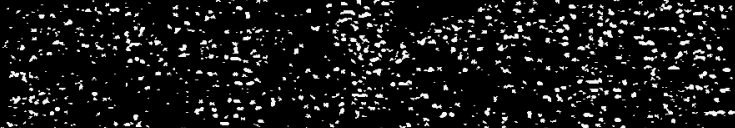

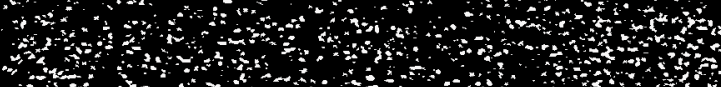

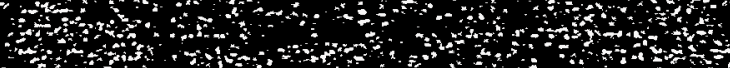

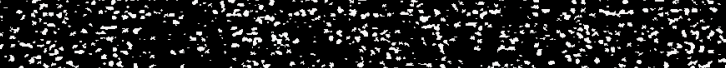

W

$40+2$

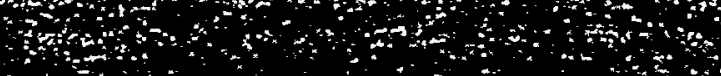

for
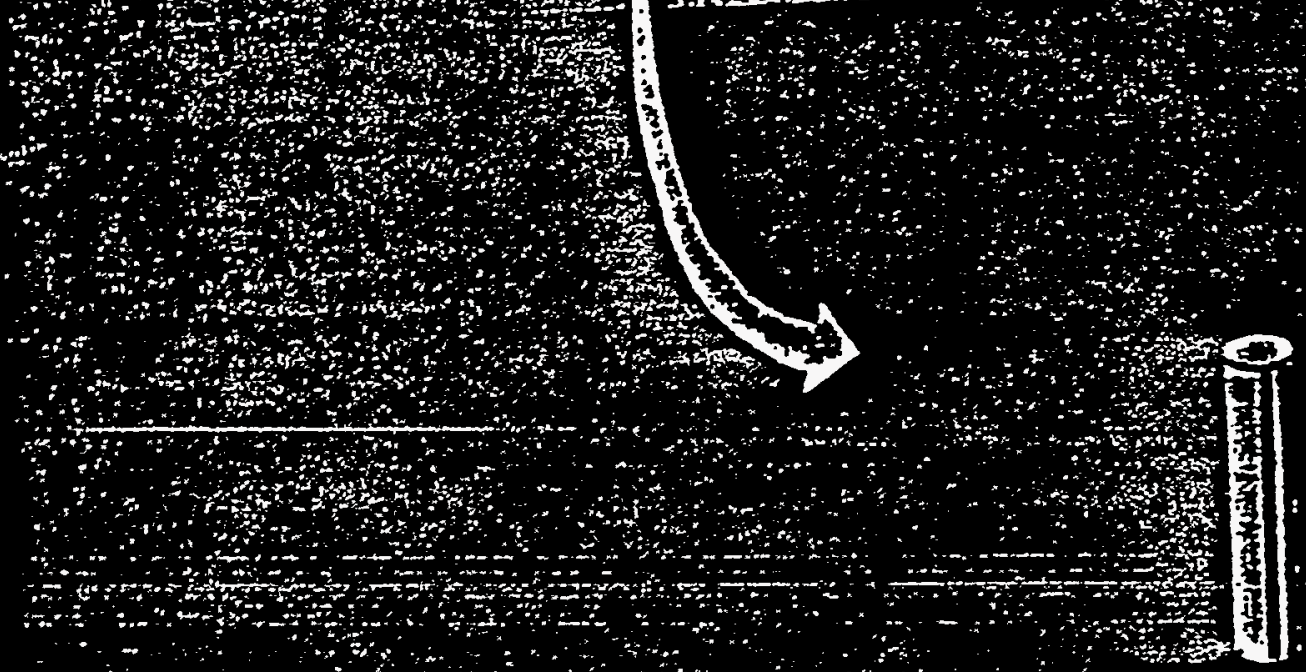

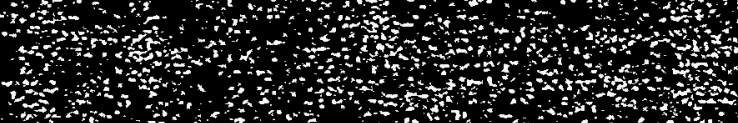

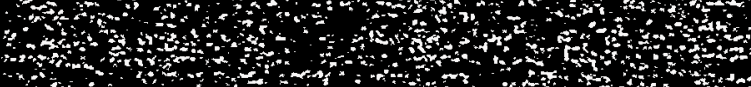
(1)
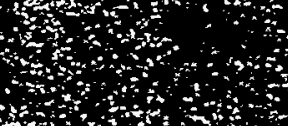

asd

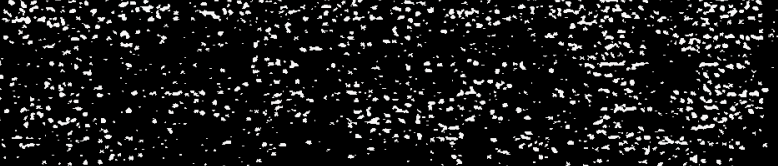

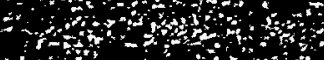

(n) 